\title{
Machaeracanthus goujeti n. sp. (Acanthodii) from the Lower Devonian of Spain and northwest France, with special reference to spine histology
}

\author{
Héctor BOTELLA \\ Department of Geology, University of Valencia, \\ c/ Doctor Moliner, 50, E-46100, Burjassot Valencia (Spain) \\ hector.botella@uv.es
}

Carlos MARTÍNEZ-PÉREZ

School of Earth Sciences, University of Bristol, Wills Memorial Building, Queen's Road, Bristol, BS8 1RJ (United Kingdom) and Department of Geology, University of Valencia, c/ Doctor Moliner, 50, E-46100, Burjassot Valencia (Spain) carlos.martinez-perez@bristol.ac.uk

Rodrigo SOLER-GIJÓN
Facultad CC, Geológicas, Universidad Complutense,
Departamento de Paleontología,
c/ José Antonio Novais, 12, Ciudad Universitaria, E-28040 Madrid (Spain)
and Museum für Naturkunde, Leibniz Institute for Research
on Evolution and Biodiversity at the Humboldt University Berlin,
Invalidenstrasse 43, D-10115 Berlin (Germany)
rodrigo.soler-gijon@mfn-berlin.de

Botella H., Martínez-Pérez C. \& Soler-Gijón R. 2012. - Machaeracanthus goujeti n. sp. (Acanthodii) from the Lower Devonian of Spain and northwest France, with special reference to spine histology. Geodiversitas 34 (4): 761-783. http://dx.doi.org/10.5252/g2012n4a3

\section{ABSTRACT}

We describe here a new machaeracanthid acanthodian (Machaeracanthus goujeti n. sp.), based on isolated spines, scales and scapulocoracoids from the Lower Devonian (Lochkovian-Pragian) of the Nogueras Formation, Celtiberia, Spain. The new taxon also includes a fragmentary spine and isolated scales from the Lower Devonian of northern Spain (Palencia and Cantabrian Mountains) and western France (Saint-Céneré) originally assigned to Machaeracanthus sp. The spines of $M$. goujeti n. sp. comprise two morphotypes in agreement with the morphofunctional model of a pair of pectoral spines articulating with the pectoral girdle already indicated for $M$. hunsrueckianum Südkamp \& Burrow, 2007, M. longaevus Eastman, 1907, and M. sulcatus Newberry, 1857. The morphology and size of the spines distinguish $M$. goujeti $\mathrm{n}$. sp. from the coeval species M. bohemicus Barrande, 1872; the new species most closely resembles the younger species $M$. peracutus Newberry, 1857. The spines of $M$. goujeti n. sp. consist of trabecular and lamellar dentine layers which form the wall of 
KEY WORDS

Machaeracanthus,

Acanthodii fin spines,

Lochkovian-Pragian,

Celtiberia,

Spain, new species.

MOTS CLÉS

Machaeracanthus, Aiguillons pectoraux,

Acanthodiens,

Lochkovien-Praguien,

Celtiberie,

Espagne,

espèce nouvelle. the central axis (pierced by a longitudinal pulp cavity) and lateral expansions. The most superficial layer of dentine is centrifugally deposited in the complete spine; this condition is found in fin spines of some chondrichthyans and contrasts with that observed in typical acanthodian fin spines where the exserted portion is ornamented with ribs of centripetally growing dentine. Very small spines and scapulocoracoids of $M$. goujeti $\mathrm{n}$. sp. described here, are the first report of juvenile specimens of a species of Machaeracanthus Newberry, 1857. The distal part of the juvenile spine lacks lateral expansions (keel and wing) and demonstrates the first stage in the development of the spine.

\section{RÉSUMÉ}

Machaeracanthus goujeti $n$. sp. (Acanthodii) du Dévonien inférieur d'Espagne et du Nord-Ouest de la France, avec une attention particulière sur l'histologie des épines. Nous décrivons ici une nouvelle espèce d'acanthodien machaeracanthide (Machaeracanthus goujeti $\mathrm{n}$. sp.) sur la base d'aiguillons, d'écailles et de scapulocoracoïdes isolés du Dévonien inférieur (Lochkovien-Praguien) de la Formation Nogueras (Celtibérie, Espagne). Ce nouveau taxon comprend un fragment d'aiguillon ainsi que des écailles isolées provenant du Dévonien inférieur du nord de l'Espagne (Palencia et Cordillère Cantabrique) et du Nord-Ouest de la France (Saint-Cénéré) qui avaient été attribués originellement à Machaeracanthus sp. Les aiguillons de $M$. goujeti $\mathrm{n}$. sp. se divisent en deux morphotypes en concordance avec le modèle d'aiguillons pectoraux pairs s'articulant sur la ceinture pectorale, comme déjà établi pour M. hunsrueckianum Südkamp \& Burrow, 2007, M. longaevus Eastman, 1907 et $M$. sulcatus Newberry, 1857. La forme et la taille des aiguillons de $M$. goujeti n. sp. se distinguent de celles de l'espèce contemporaine $M$. bohemicus Barrande, 1872; le nouveau taxon ressemble plus à l'espèce plus récente M. peracutus Newberry, 1857. Les aiguillons de M. goujeti n. sp. se composent de couches de dentine lamellaires et trabéculaires formant la paroi de l'axe central (percé d'une cavité pulpaire longitudinale), ainsi que les expansions latérales. Les couches de dentine les plus superficielles ont été déposées de façon centrifuge dans tout l'aiguillon; cette condition se retrouve dans les aiguillons de certains chondrichthyens et contraste avec celle observée chez les aiguillons d'acanthodiens «typiques", où la partie libre de l'aiguillon est ornementée de côtes et montre une croissance centripète de la dentine. Des aiguillons et ceintures pectorales de très petites tailles constituent la première occurrence de spécimens juvéniles de Machaeracanthus Newberry, 1857. La partie distale de ces épines juvéniles ne montre pas d'expansions laterales (quille et aile) et démontre ainsi l'absence de ces structures dans les premiers stades de développement.

\section{INTRODUCTION}

The genus Machaeracanthus Newberry, 1857 (Late Silurian to Middle Devonian; Burrow et al. 2010a), was originally erected for large isolated fish spines from the Eifelian (early Middle Devonian) "Cornifer- ous" limestones of Ohio, USA, assigned to the type species $M$. peracutus Newberry, 1857. Currently, the genus includes eleven valid species distributed worldwide (for a historical review of Machaeracanthus species, see Zidek 1981 and more recently Burrow et al. 2010b). Most of these species are 
known exclusively from spines (i.e. $M$. peracutus; M. polonicus Gürich, 1901; M. longaevus Eastman, 1907; M. westfalicus Pfeiffer, 1938 and M. hunsrueckianum Südkamp \& Burrow, 2007). However other species are defined on exo- and endoskeletal elements, associated or not to spines. In this respect, M. bohemicus Barrande, 1872 is known for spines, scales, scapulocoracoids and a fragmentary tooth (Barrande 1872; Fritsch 1893; Gross 1973; Zidek 1975); M. pectinatus Burrow \& Young, 2005 is known from scales, possibly fin rays (but see discussion below) and probably scapulocoracoids (Burrow et al. 2010b: 61). Machaeracanthus kayseri Kegel, 1913 and M. sulcatus Newberry, 1857 are known for spines and scapulocoracoids (Kegel 1913; Gross 1933; Burrow et al. 2010b). Machaeracanthus major Newberry, 1857 was erected based on isolated spines (Newberry 1857), although Burrow et al. (2010b) identified a scapulocoracoid in the Cleveland Museum of Natural History collection belonging to $M$. cf. major. Machaeracanthus stonehousensis (Legault, 1968) is the only species known solely for its scales. In consequence, with all this information, Burrow \& Young (2005) erected the Family Machaeracanthidae, providing a diagnosis (recently revised in Burrow et al. 2010b) which includes characters of spines, scales and scapulocoracoids.

The affinities of Machaeracanthus are uncertain. The genus has traditionally been assigned to Acanthodii (Denison 1979) and the Order Ischnacanthiformes (Zidek 1975, 1981; Young 1986; Webers et al. 1992; Maisey et al. 2002; Maisey \& Melo 2005; Südkamp \& Burrow 2007). However, the systematic position of Machaeracanthus has become more uncertain in recent years in the context of the rejection of acanthodian monophyly by several workers (Janvier 1996; Brazeau 2009). Burrow \& Young (2005) and Burrow et al. (2010b) considered Machaeracanthus as the type genus of the acanthodian family Machaeracanthidae, tentatively included in Ischnacanthiformes or in an Order incertae sedis. Finally, Hanke \& Wilson (2010: 179) suggested that asymmetrical fin spines, including those of Machaeracanthus, "may actually represent stem chondrichthyans or stem members of the teleostome plus chondrichthyan clade".

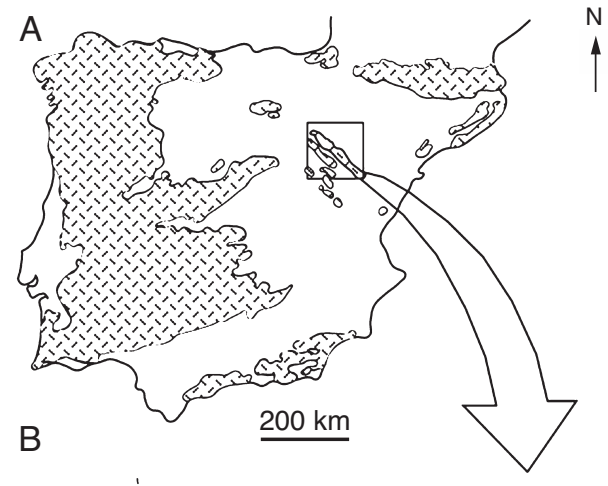

Mesones Ún:

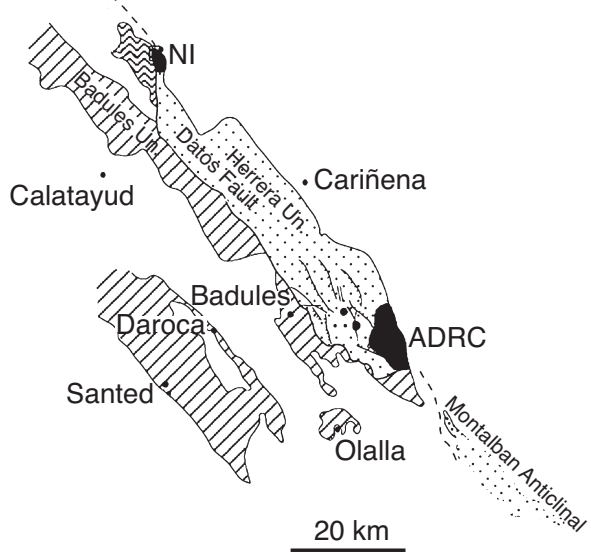

$\because$ Precambrian and Hercynian outcrops of the Iberian Peninsula

72 Badules Unit (Precambrian-Ordovician)

Herrera Unit (Upper Cambrian-Devonian)

Е Mesones Unit (Lower-Middle Cambrian)

FIG. 1. - A, Geographical setting of the studied area with indication of the distribution of Precambrian and Palaeozoic rocks in the Iberian Peninsula; B, geological map of Palaeozoic rocks in the Iberian chains pointing out the two studied areas (Devonian outcrops in black). Abbreviations: ADRC, axial depression of the Río Camaras (Carls 1988); NI, axial depression of Nigüella (Valenzuela-Ríos 1989).

In the present work we describe new disarticulated material, consisting of spines, scales and five scapulocoracoids assigned to the acanthodian genus Machaeracanthus, that occur recurrently together in several levels of the Lower Devonian sediments of the Nogueras Fm. (Celtiberia, Spain) and 
propose including all of them in a unique natural assemblage, Machaeracanthus goujeti n. sp. New data provided here increase our knowledge on the evolutionary history and taxonomic diversity the group reached during Early Devonian time. The chemical processing of sediment has led to recovery of very well preserved microremains, mainly scales and juvenile spines, which allow study for the first time of the early ontogenetic stages in spines of a Machaeracanthus species.

\section{MATERIAL AND METHODS}

All the material studied here come from different outcrops of the Nogueras Formation (LochkovianPragian, Lower Devonian) in two different areas of Celtiberia (Spain; see Fig. 1): 1) the Axial Depression of the Río Cámaras (ADRC; Carls 1988) more specifically from the localities Barranco Sur Santo Domingo, Poyales-East, Maripló and Viñas (see Carls 1988; Dojen 2005); and 2) the Axial Depression of Nigüella (NI; Valenzuela-Ríos 1989), sections $\mathrm{Ni}-2$ and Ni-4 (see Valenzuela-Ríos \& Botella 2000). The ADRC is located in the south-eastern part of the Iberian Chains (Teruel Province) and NI is situated in its north-eastern part (Zaragoza Province; see Fig. 1). The Nogueras Fm. consists of a 140-150 m thickness of shallow-marine deposits with bioclastics limestones, marls and arenaceous shales (Fig. 2). This formation includes the "Leitbank A" (bed A), located between the local boundary $\mathrm{d} 2 \mathrm{~b} \alpha / \mathrm{d} 2 \mathrm{~b} \beta$, a laterally continuous dark mudstone bed, $35-50 \mathrm{~cm}$ in thickness, which corresponds almost exactly to the Lochkovian/Pragian boundary. The most important biostratigraphic marker is the brachiopod Vandercammenina sollei Carls, 1986, which indicates the beginning of the Pragian in rhenish facies (Carls \& Valenzuela-Ríos 2002). A little below bed A, chitinozoans of the Lochkovian/Pragian boundary occur (Morzadec et al. 1991). The upper 80 metres of the Nogueras Fm. (submembers $d 2 c \alpha$ to $d 2 c \beta$ ) are Pragian in age. Remains assigned here to Machaeracanthus goujeti $\mathrm{n}$. sp. occur in numerous levels around the Lochkhovian-Pragian boundary (submembers $\mathrm{d} 2 \mathrm{a} \alpha$ to $d 2 c \alpha$, see Fig. 2). Most of the material comes from the dissolution of limestone rocks with formic acid (5-10\%), although a number of the largest spines are preserved in marly sandstone slabs.

Specimens were photographed with a Leica MZ12 binocular microscope connected to a digital camera "Leica" DFC420 and with a Scanning Electron Microscope (Philips XL-30) hosted at Electron Microscopy Service of the University of Valencia. For the histological study the spines and scales were embedded in Canada balsam and polished subsequently along transverse or longitudinal planes. The material, once prepared, was photographed with a petrographic microscope (James Swift England) connected to a digital camera. All Machaeracanthus remains studied here are reposited in the Museum of Paleontology at the University of Zaragoza (MPZ) and at the Museum of Geology of the University of Valencia (MGUV).

\section{ABBREVIATIONS}

\section{Institutional abbreviations}

MB Museum für Naturkunde, Berlin;

MGUV Museum of Geology of the University of Valencia;

MPZ Museum of Paleontology of the University of Zaragoza.

\section{Figure abbreviations}

(see Figure 3 for morphological features)

ad altered dentine;

cbo cellular bone;

cfld centrifugally growing lamellar dentine;

cftrd centrifugally growing trabecular dentine;

cptrd centripetally growing trabecular dentine;

de denteon;

dend distal end;

$\mathrm{dt} \quad$ dentinal tubule;

gl growth lamella;

gm growth mark;

ide interdenteonal area;

igsp interglobular space (false bone cell lacuna);

k keel;

lac lacuna;

llr longitudinal ridge (lower surface);

ls longitudinal striae;

md mesodentine;

oc osteocyte cavity;

opc opening of the pulp cavity;

pc pulp cavity;

pend proximal end;

shf Sharpey's fibers; 
A

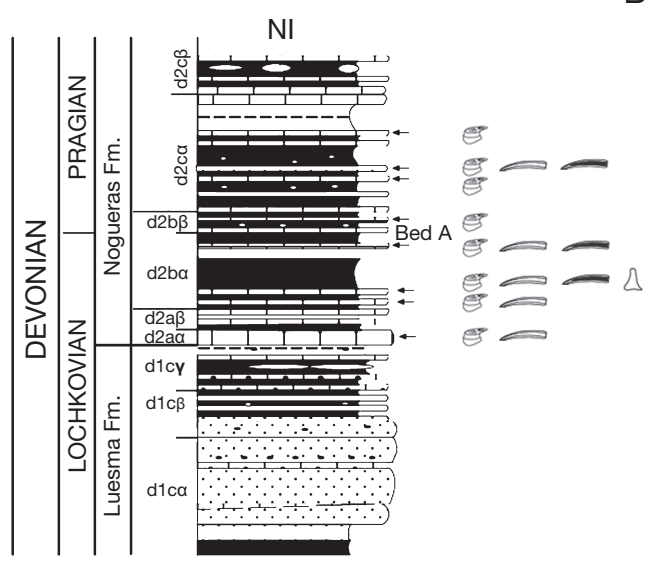

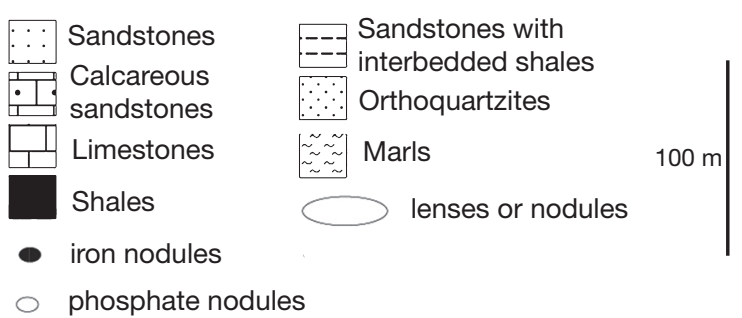

B

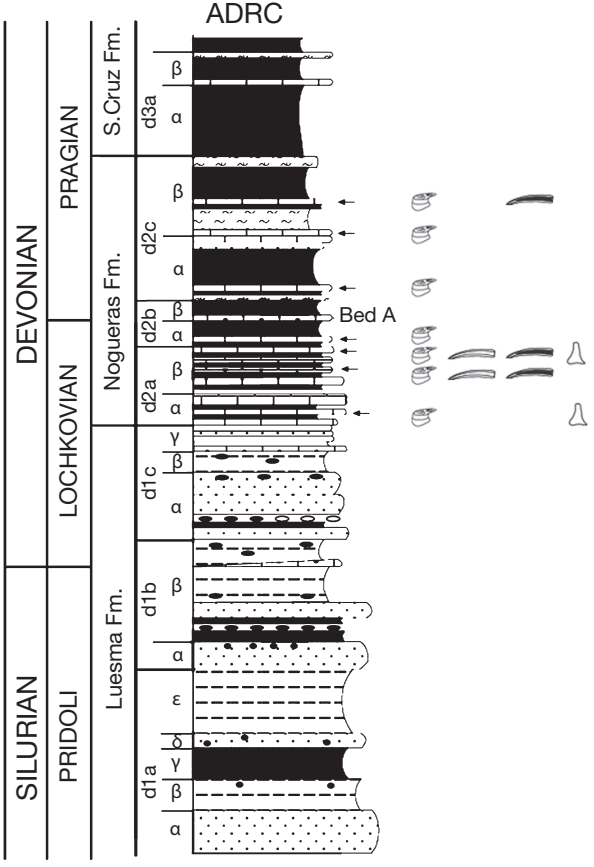

Machaeracanthus goujeti n. sp. remains

scales

Morphotype 1 spine

Morphotype 2 spine

scapulocoracoids

FIG. 2. - Synthetic columns of the axial depression of Nigüella (NI) (A) and of the axial depression of the Río Cámaras (ADRC) (B) with the distribution of the different types of remains attributed to Machaeracanthus goujeti $\mathrm{n}$. $\mathrm{sp}$. from the Lochkovian-Pragian strata of the Nogueras Fm. (modified from Valenzuela-Ríos \& Botella 2000; Botella \& Valenzuela-Ríos 2005).

ulr longitudinal ridge (upper surface);

ve vascular canal;

w wing.

\section{SYSTEMATICS}

Class ACANTHODII Owen, 1846

Order incertae sedis Family MACHAERACANTHIDAE

Burrow \& Young, 2005

Genus Machaeracanthus Newberry, 1857
Machaeracanthus goujeti $\mathrm{n} . \mathrm{sp}$.

(Figs 3-10)

Machaeracanthus sp. - Goujet 1976: 313, pl. 61, figs 3-17; pl. 63, fig. 1a, b; text-fig. 54A-E. - Wang 1993: 143, pl. 14, fig. 13. - Fernández-Herrero et al. 2009: 180, figs 2, 3. - Burrow et al. 2010b: 60.

Machaeracanthus sp. A - Mader 1986: 30, pl. 3, figs 3-5, 7-11; text-figs 10c, b; 11a, b. - Wang 1993: 141, pl. 15, figs 1-8; text-fig. 21E-H. — Botella \& Valenzuela-Ríos 2005: 126, fig. 11 .

Machaeracanthus? sp. - Mader 1986: 31, pl. 1, fig. 8.

TYPE SPECIES. — Machaeracanthusperacutus Newberry, 1857. Machaeracanthus sp. B - Wang 1993: 143, pl. 15, figs 9, 10. 
Machaeracanthus stonehousensis - VALENZUELA-Ríos \& BOTELla 2000: 150, text-figs 3, 6.

Holotype. - MPZ 2010/948 (Fig. 4A); a complete spine, c. $53 \mathrm{~mm}$ long, slightly damaged at distal end, preserved in a marly sandstone slab from the late Lochkovian (Nogueras Fm.) of the Locality Poyales-East.

PARATYPeS. - A complete spine, $50 \mathrm{~mm}$ long, from the late Lochkovian of the Nogueras Fm. (MPZ 2009/28, Fig. 4B) from the Mariplo Locality (ADRC); and scales including MGUV-15.075 to MGUV-15.082 and MPZ 2010/949 (Fig. 9) from the Localities Barranco Sur Santo Domingo and Poyales-East (ADRC) and Nigüella (NI), Nogueras Fm.

ETyMology. - In honour of Dr. Daniel Goujet for his important contributions to the knowledge of the early vertebrates. He described for the first time, scales now assigned to $M$. goujeti n. sp. from the Lower Devonian of Saint-Céneré (France).

Type locality and Horizon. - Poyales-East, Axial Depression of the Río Cámara (ADRC), Iberian Chains (Spain). Lower Devonian, Late Lochkovian (unit d2a 35 ).

GEOGRAPHICAL AND STRATIGRAPHICALDISTRIBUTION. In Celtiberia the stratigraphical distribution of Machaeracanthus goujeti n. sp. ranges from the Upper Middle Lochkovian to the Lower Pragian, submembers $\mathrm{d} 2 \mathrm{a} \alpha$ to $\mathrm{d} 2 \mathrm{c} \beta$ (Nogueras Fm.). Machaeracanthus goujeti $\mathrm{n}$. sp. has also been recovered from the Lochkovian and Pragian of Saint-Céneré Fm. (northwest France), from the Upper Lochkovian and Lower Pragian of Lebanza Fm. in Palencia and La Vid Fm. in León (Cantabrian Mountains, North Spain).

Material eXAmined. - More than 1000 scales, more than 50 spines and 5 scapulocoracoids from the localities Barranco Sur Santo Domingo, Poyales-East, Maripló and Viñas sections from ADRC (see Carls 1988; Dojen 2005) and sections $\mathrm{Ni}-2$ and $\mathrm{Ni}-4$ from NI (Valenzuela-Ríos 1989; Valenzuela-Ríos \& Botella 2000).

Diagnosis. - Machaeracanthus species with relatively slender spines with a maximum width to length ratio c. 1:7; two morphotypes can be distinguished, both showing narrow lateral expansions (keel and wing) of similar width (upper surface view); morphotype 1 is represented by spines with longitudinal striation mainly on the proximal third, and showing, in cross section, a triangular to sub-triangular longitudinal ridge on the upper surface and a more rounded longitudinal ridge on the lower surface; morphotype 2 is represented by densely striated spines which present, in cross section, a subsquare-shaped longitudinal ridge on the upper surface and a rounded and broader longitudinal ridge on the lower surface. Scales with eight to twelve ridges which converge from the anterior part to the centre of the crown and diverge posteriorly; the ridges extending behind the upper part of the neck, never reach the base; neck is pronounced, presenting a slight narrowing; base moderately convex. Mesodentine forms most of the crown, and the base is formed by cellular bone with bone cell lacunae arranged parallel to growth lines.

\section{DESCRIPTION}

Spine morphology (Figs 3; 4A-K; 5)

More than 50 spines, from nearly complete to very fragmentary specimens, were studied. The preserved material indicates a wide range of sizes suggesting the assemblage of remains belonging to individuals of different ontogenetic stages (see below). The smallest complete specimen (Fig. 3;MPZ 2010/950) is a spine $1 \mathrm{~cm}$ long and $2.6 \mathrm{~mm}$ in maximum width (maximum width to length ratio $c .1: 4$, characteristic of juvenile individuals; see discussion below). The holotype and paratype MPZ 2010/948 and MPZ 2009/28 (Fig. 4A, B), represented by nearly complete specimens, are very similar in size, about $53 \mathrm{~mm}$ long and $7.5 \mathrm{~mm}$ in maximum width (maximum width to length ratio $1: 7$, a ratio considered as characteristic of adult individuals and included in the diagnosis of the new species). However, several large fragmentary spines indicate the presence in the locality of bigger specimens. For example, specimen MPZ 2010/951 and MPZ 2009/26 (see Fernández-Herrero et al. 2009: fig. 2B) are about $1.5 \mathrm{~cm}$ in maximum width pointing to complete spines more than $10 \mathrm{~cm}$ long. All the spines are asymmetrical, curved posteriorly and have a characteristic saber shape with a thick central axis (the body of the spine) and two narrow lateral expansions, an anterior keel and a posterior wing. As shown in specimen MPZ 2010/950 (Fig. 3), the lateral expansions start close to the distal termination of the spine, gradually increase their width in proximal direction to reach the maximum and then decrease in width to the proximal termination of the spine. Upper surfaces of keel and wing exhibit a similar width with the exception of the most proximal part of the spine where the keel is narrower than the wing. Concerning the lower side, the keel is narrower than the wing along the whole spine. Two different morphotypes can be recognised according to the morphology in transverse section of the 

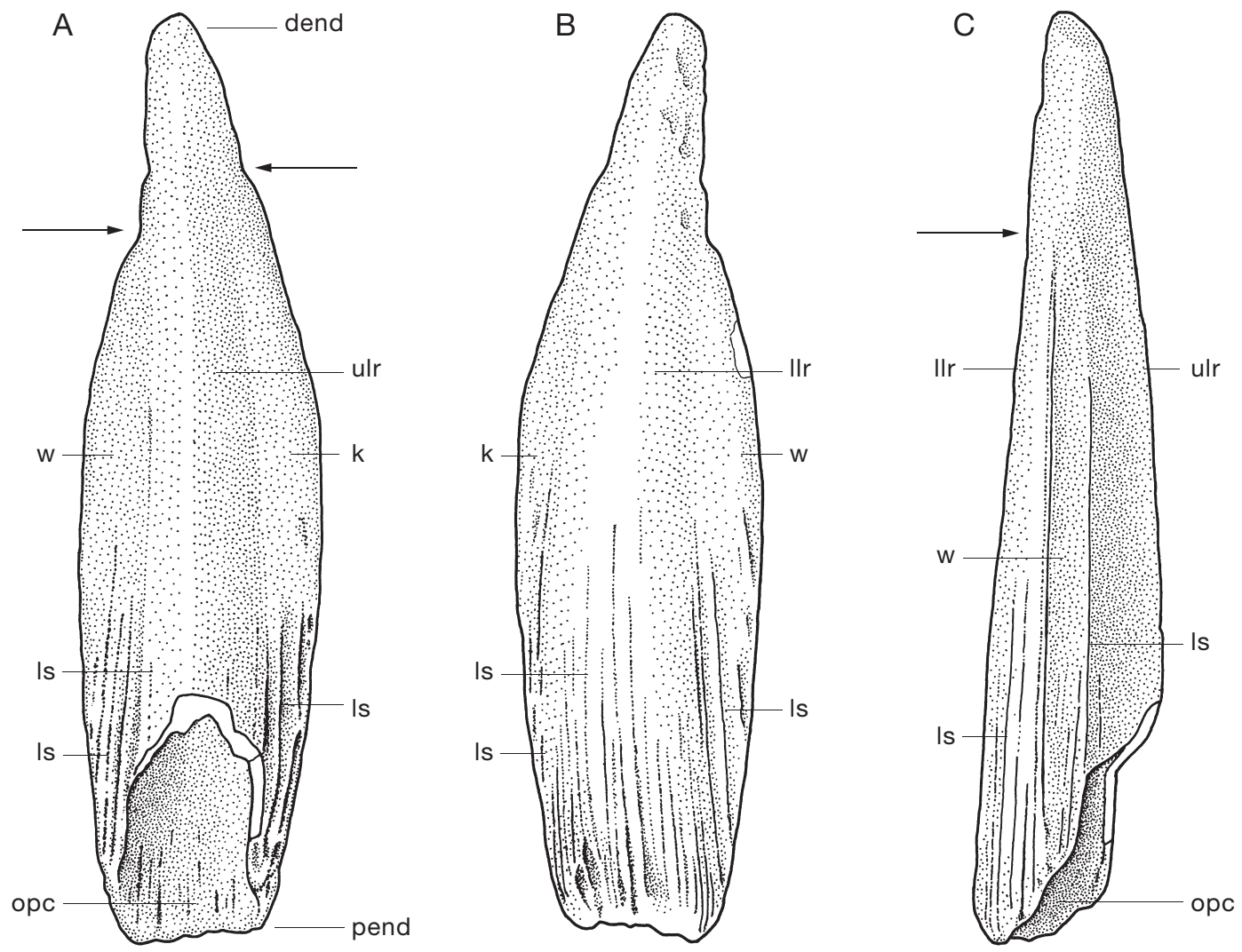

FIG. 3. - Machaeracanthus goujeti n. sp.; Lower Devonian, Iberian Chain; juvenile spine (morphotype 1) (MPZ 2010/950), Nogueras Fm., section Maripló (ADRC); Mpl26): A, upper surface view; B, lower surface view; C, trailing edge view. Arrows point to the distal end of wing and keel. Abbreviations: see Material and methods. Scale bar: $1 \mathrm{~mm}$.

upper and lower parts of the central axis (upper and lower longitudinal ridges following the terminology of Burrow et al. 2010b) and the development of longitudinal striation. The morphotype 1, including the holotype MPZ 2010/948 (Figs 3; 4A, F-I), is characterised by spines with, in cross section, a triangular to sub-triangular upper longitudinal ridge and a more rounded lower longitudinal ridge on the lower surface, with some spines having a slightly asymmetrical triangular upper ridge (Figs $4 \mathrm{~K} ; 5 \mathrm{~A}$, B). The longitudinal striation on the upper side occurs in the proximal third of the spine whereas in the lower side it extends for one third or more of the spine (Figs 3; 4F-I; 5A-C). Morphotype 2, including paratype MPZ 2009/28 (Fig. 4B), is characterised by having a narrowly subsquare-shaped upper longitudinal ridge and a rounded and broader lower longitudinal ridge (Figs 4J; 5D). A dense longitudinal striation occurs along the upper and lower sides of the complete spine except along the most distal part (Fig. 4C-E). The upper surfaces of the spines show a longitudinal groove at the junction of the upper longitudinal ridge and the lateral expansions that in some elements appears as a secondary expansion or double edge (more marked on the keel joining) in cross section.

\section{Spine histology (Figs 5-8)}

The histological structure of the spines changes from distal to proximal ends (Figs 5-8). A pulp 
cavity extends along the central axis of the spine (Fig. 5); the cavity is very narrow in the distal part of the spine, becomes wider proximally and opens at the most proximal end of the spine (Fig. 3A, C). At the proximal part of the spine, the pulp cavity is higher than wide (transverse section view) in morphotype 1 and nearly rounded to wider than high in the morphotype 2 (Fig. 5).

The wall of the central axis (body of the spine) and lateral expansions (keel and wing) consist of trabecular and lamellar dentine.

Centripetally growing trabecular dentine surrounds the pulp cavity in the distal and middle parts of the spine (Figs 5A, B, D; 6A; 7A). Centrifugally growing trabecular dentine surrounds the pulp cavity proximally (Figs 5C; 8A), covers the centripetally growing trabecular dentine in the mid-and distal parts of the spine and extends laterally to form the internal and main part of the keel and wing (Figs 5; $6 \mathrm{~A} ; 7 \mathrm{~A} ; 8)$. There is no evidence of sharp structural discontinuity between centripetal and centrifugal trabecular dentines, but both hard tissues can be easily distinguished by the difference in the dimension of the intertrabecular spaces (see below). In addition, growth marks in the trabecular dentine are also less apparent than in the lamellar dentine.

Centrifugal lamellar dentine with clear growth marks covers the centrifugal trabecular dentine at least in the distal half of the spines (morphotypes 1 and 2) (Figs 6; 7A, B).

Vascular pattern of the centripetally growing trabecular dentine is extremely regular as observed in transverse section (Figs 5A, B, D; 6A; 7A). Rows of round cavities and fairly straight canals radiate from the pulp cavity and connect with the centrifugal trabecular dentine. The round cavities represent the transverse sections of longitudinal canals. In general view, the intertrabecular spaces are wider in the centripetal dentine than in the centrifugal one.

Denteons around the vascular canals and interdenteonal areas can be distinguished in sections with less taphonomic alteration (Fig. 7). Dentinal tubules radiating from the vacular canals form a dense network in the borders of denteons and in the interdenteonal areas (Fig. 7B, C). Numerous interglobular spaces appear in the interdenteonal areas (Figs 7C; 8B). The spaces are usually filled by opaque authigenic minerals and present evidence of severe alteration postmortem in some regions of the spines (Fig. 8B; see discussion below).

The most superficial layer of dentine, centrifugally deposited, is pierced by dentinal tubules that exhibit their finer distal branches in centripetal direction (Fig. 6B, C). Consequently, there is no evidence of hypermineralized enameloid.

\section{Scale morphology (Fig. 9)}

Scales are large, 1 to $2 \mathrm{~mm}$ long and wide, and 0.6 to $1.5 \mathrm{~mm}$ height. Largest specimens are up to $2.4 \mathrm{~mm}$ long. The crown is flat, nearly parallel to the interface between the base and neck and extends posteriorly beyond the base (Fig. 9B, G, H). The crown is ornamented with a variable number of ridges (8-12) which rise from the upper part of the neck, more or less parallel along the rostral margin and then converge to the center of the crown. On

FIG. 4. - Machaeracanthus goujeti n. sp.; Lower Devonian, Iberian Chain: A-G, spines; A, holotype (morphotype 1), element MPZ 2010/948, upper side view, characterized by the absence of longitudinal striation, Nogueras Fm., section Poyales-East (ADRC); B, paratype (morphotype 2) element MPZ 2009/28 in dorsal view where is clearly visible their longitudinal striated ornamentation; Nogueras Fm., section Maripló (ADRC); C-E, spine (morphotype 2) lacking the distal and proximal parts, element MPZ 2010/953; Nogueras Fm., section Poyales-East (ADRC); C, upper view, D, lower view, E, detail of the lower side with the characteristic longitudinal striation; F, G, distal part of spine (Morphotype 1), element MPZ 2010/954, Nogueras Fm., section Maripló (ADRC); F, upper view, G, lower view, in both sides is clearly evident the absence of striation; H, I, mid-spine fragment (morphotype 1), element MPZ 2010/955 (specimen included for their histological study); Nogueras Fm., section Poyales-East (ADRC); H, upper view; I, lower view where is visible a weak longitudinal striation in the proximal part of the spine; $\mathbf{J}$, cross section view of spine (morphotype 2) showing their characteristic subsquare-shaped longitudinal ridge on the upper surface and a rounded longitudinal ridge on the lower surface, element MPZ 2010/956, Nogueras Fm., section Maripló (ADRC); K, cross section view of spine (morphotype 1) represented by smaller and smooth spines with a sub-triangular longitudinal ridge on the upper surface and a more rounded longitudinal ridge on the lower surface, element MPZ 2010/957, Nogueras Fm., section Maripló (ADRC); L, O, right scapulocoracoid, element MPZ 2010/952 from the Nogueras Fm, section Poyales-East (ADRC); $\mathbf{L}$, lateral and $\mathbf{M}$, medial view showing the gradual transition between the scapular shaft and the triangular scapulocoracoid areas; $\mathbf{N}$, upper view, showing the subcircular scapular shaft in cross section; $\mathbf{O}$, lower view showing the insertion areas of the spines, although is important to notice that the lateral scapulocoracoid blade was broken and collapsed during the photographic session. Scale bars: A-D, F-I, $1 \mathrm{~cm}$; E, J-O, $0.5 \mathrm{~cm}$. 


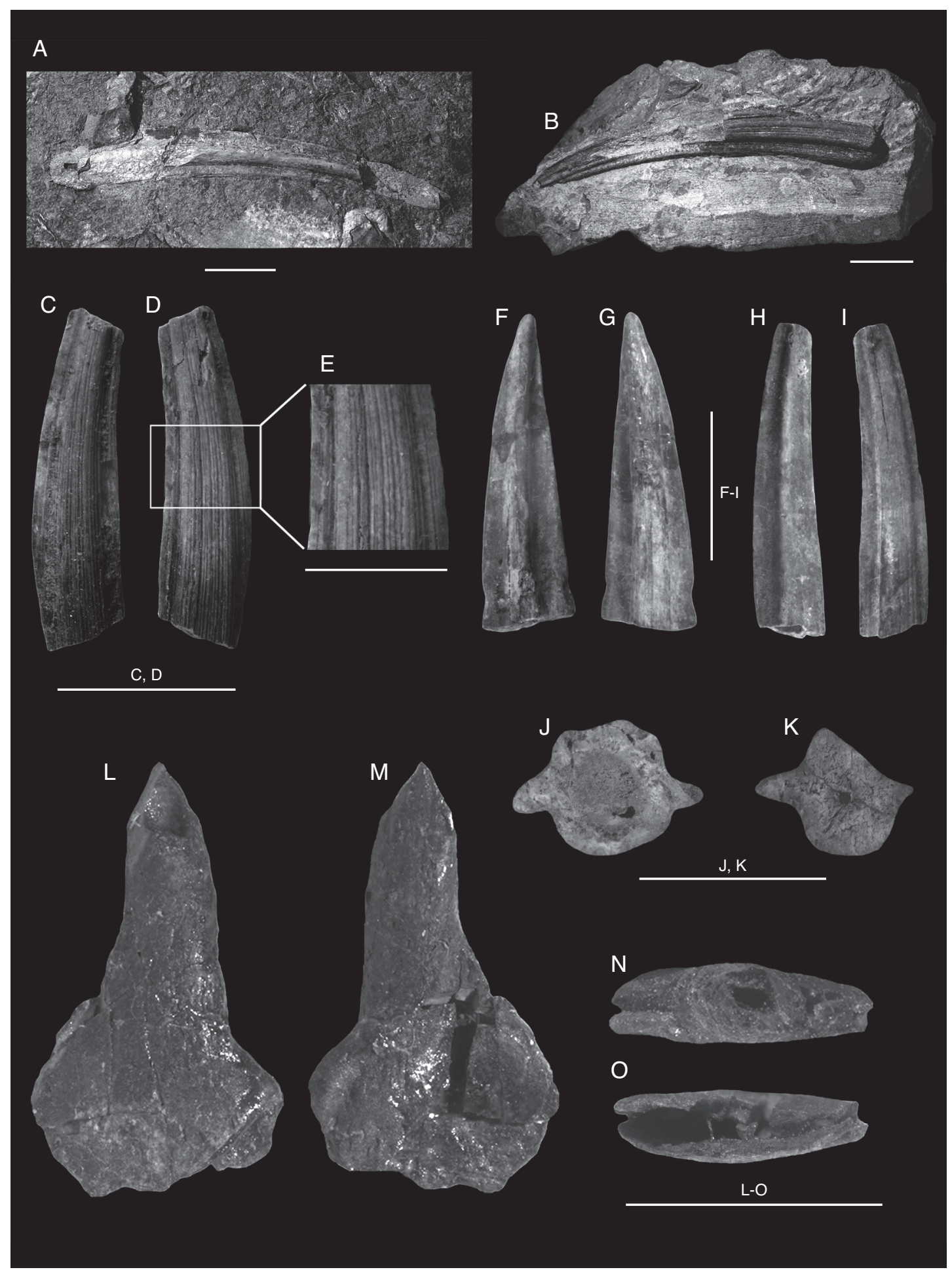



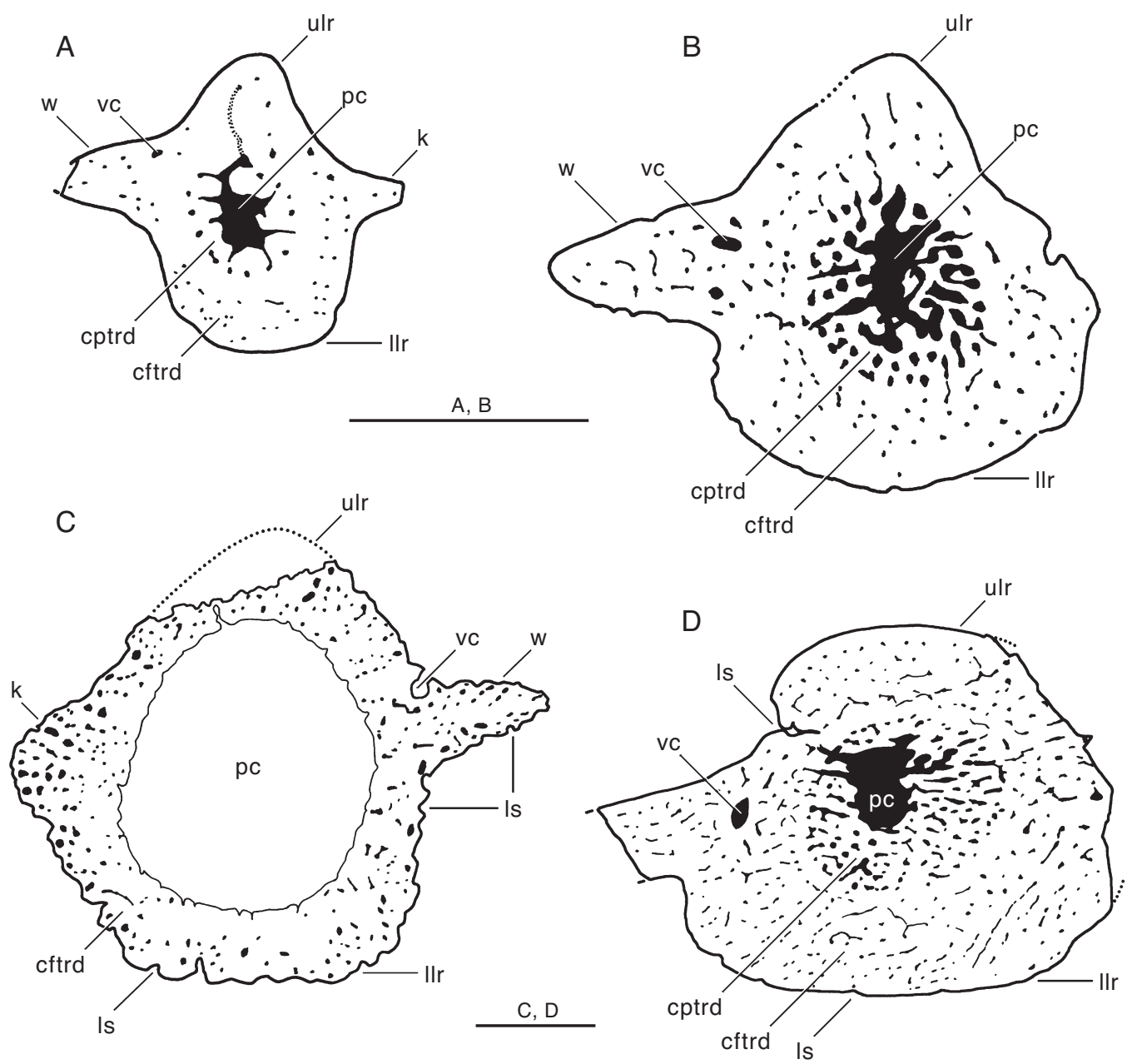

FIG. 5. - Machaeracanthus goujeti n. sp., Lower Devonian, Iberian Chain. Transverse sections of spines showing the development of pulp cavity and vascular pattern: A, distal part of spine MPZ 2010/955A, juvenile (morphotype 1), Nogueras Fm., Poyales-East (ADRC); B, middle part of spine MPZ 2010/958, juvenile (morphotype 1); C, proximal part of spine MPZ 2009/27 (morphotype 1), Nogueras Fm., Poyales-East; D, middle part spine MPZ 2010/959 (morphotype 2). Abbreviations: see Material and methods. Scale bars: 1 mm.

the posterior crown, when it is preserved, ridges diverge as radial ridges towards the caudal edge of the crown (Fig. 9A, C, E, G, L), which is divided into eight to twelve long parallel denticulations, with each of these denticulations corresponding to the end of a ridge (Fig. 9H, J, L). However, as the posterior part of the crown is thin and delicate, denticulation at the caudal margin is broken or damaged in most of the specimens (Fig. 9A, C, E). The anterior margin of the crown is rounded (Fig. 9A,
C, E, G). The neck is pronounced and presents a slight narrowing between the crown and the base (Figs. 9D, F, J). The base varies from low to moderately convex and protrudes rostrally in front of the anterior edge of the crown (Fig. 9A, C, E, L). The shape of the base is rhomboidal and smaller than the crown (Fig. 9B, H). Small vascular canal openings can be observed in the neck.

Some scales have a long and narrow crown, with a long neck; in these scales the ridges are strongly 


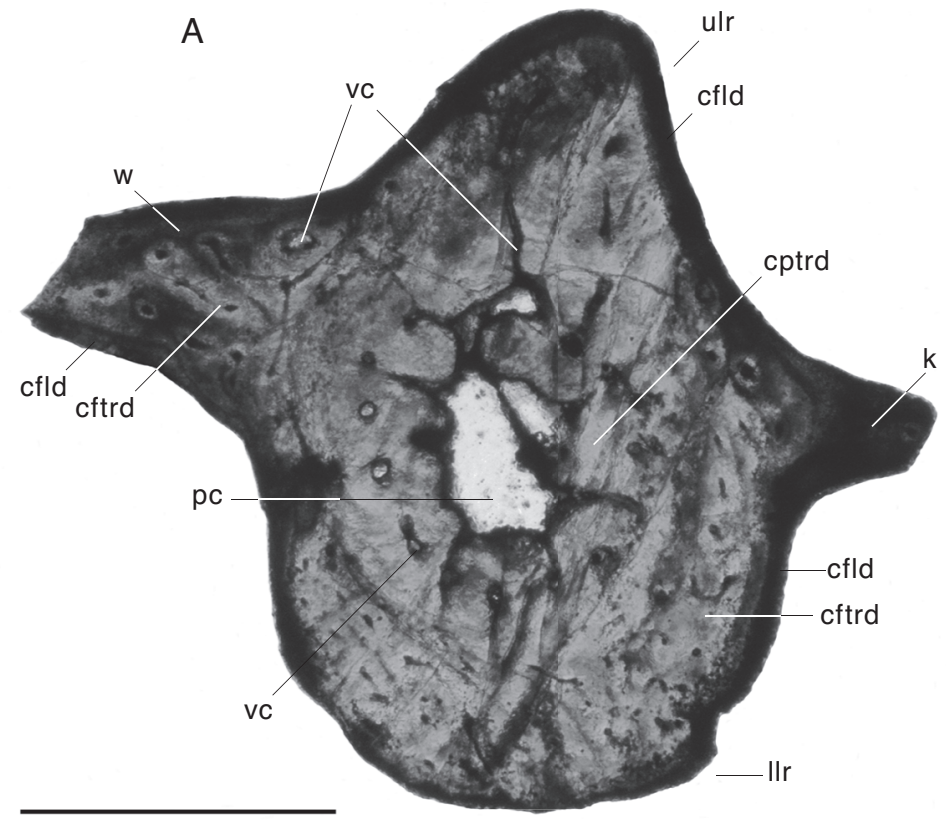

B

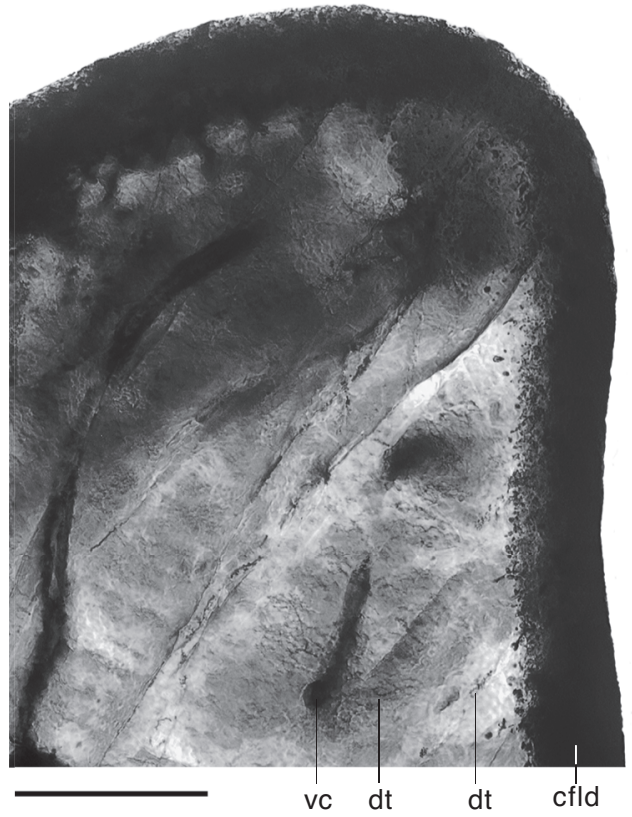

dt $\quad$ vc

dt $\quad$ cfld

C

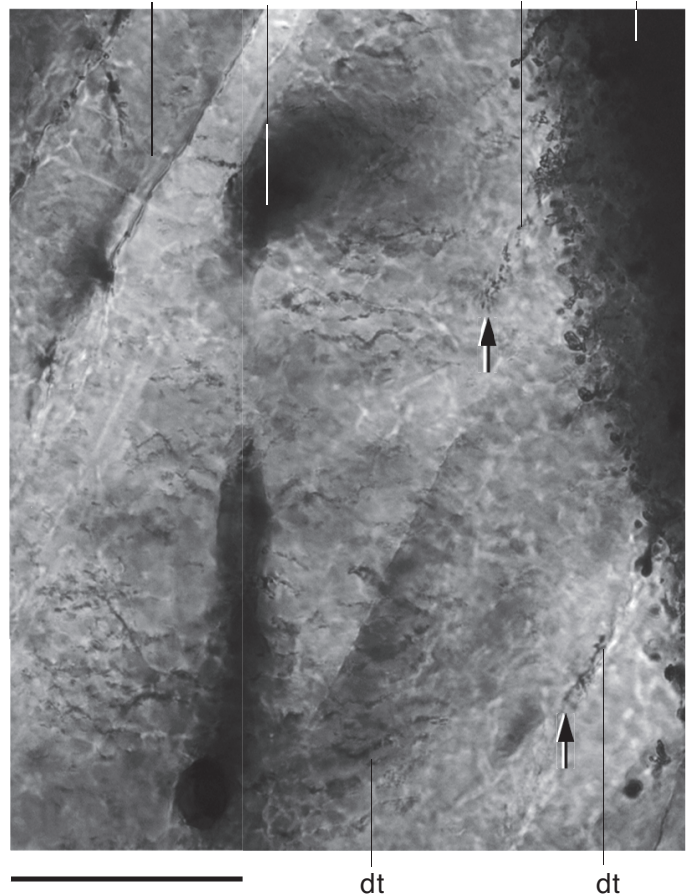

$\mathrm{dt}$

$\mathrm{dt}$

FIG. 6. - Machaeracanthus goujeti n. sp.; Lower Devonian, Iberian Chain. Transverse section of distal part of spine MPZ 2010/955A, juvenile: A, general view; B, C, details of the upper longitudinal ridge. Arrows in $\mathbf{C}$ point to distal branches of dentinal tubules. Thin section observed in transmitted ordinary light. Abbreviations: see Material and methods. Scale bars: A, $0.5 \mathrm{~mm} ; \mathrm{B}, 0.1 \mathrm{~mm} ; \mathrm{C}, 50 \mu \mathrm{m}$. 

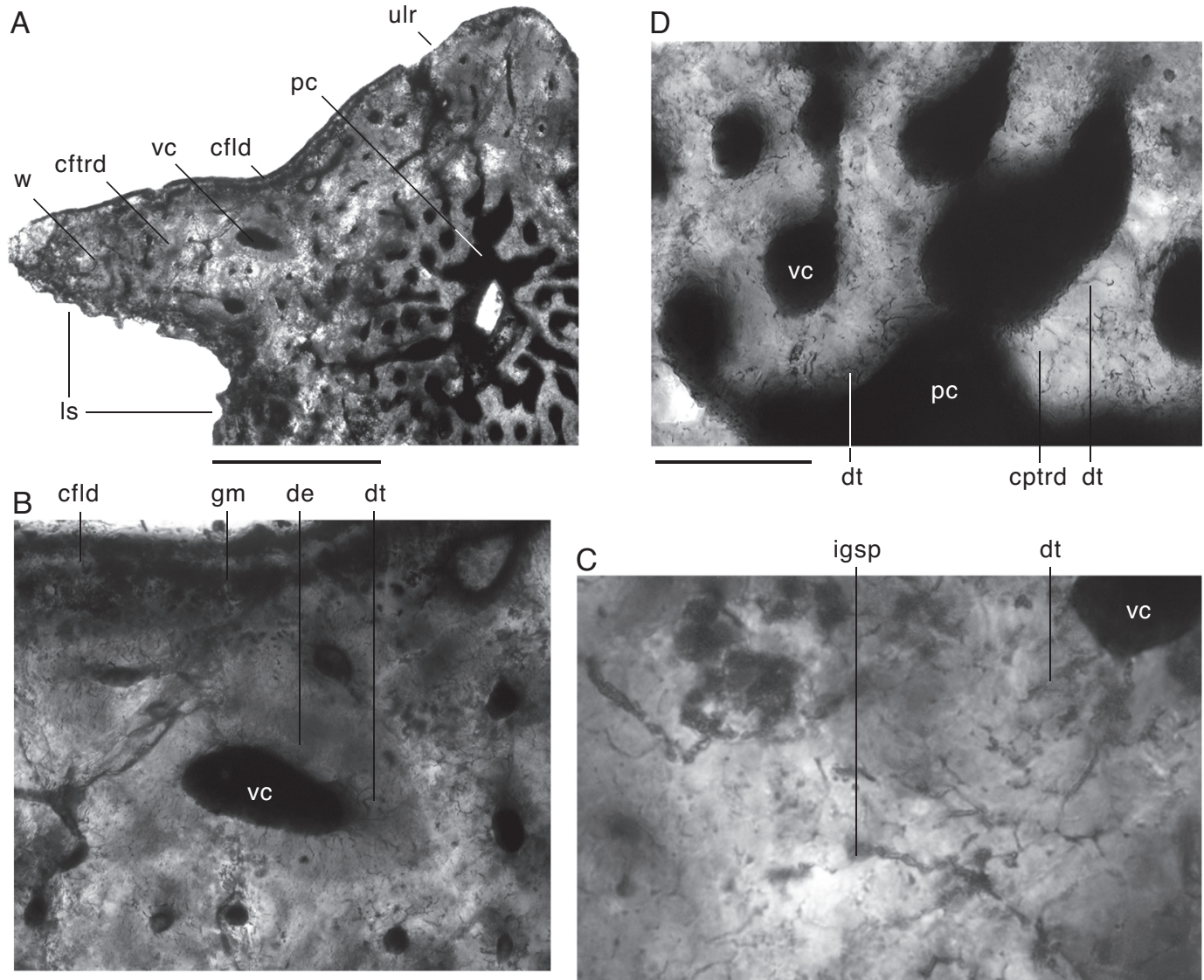

C igsp dt

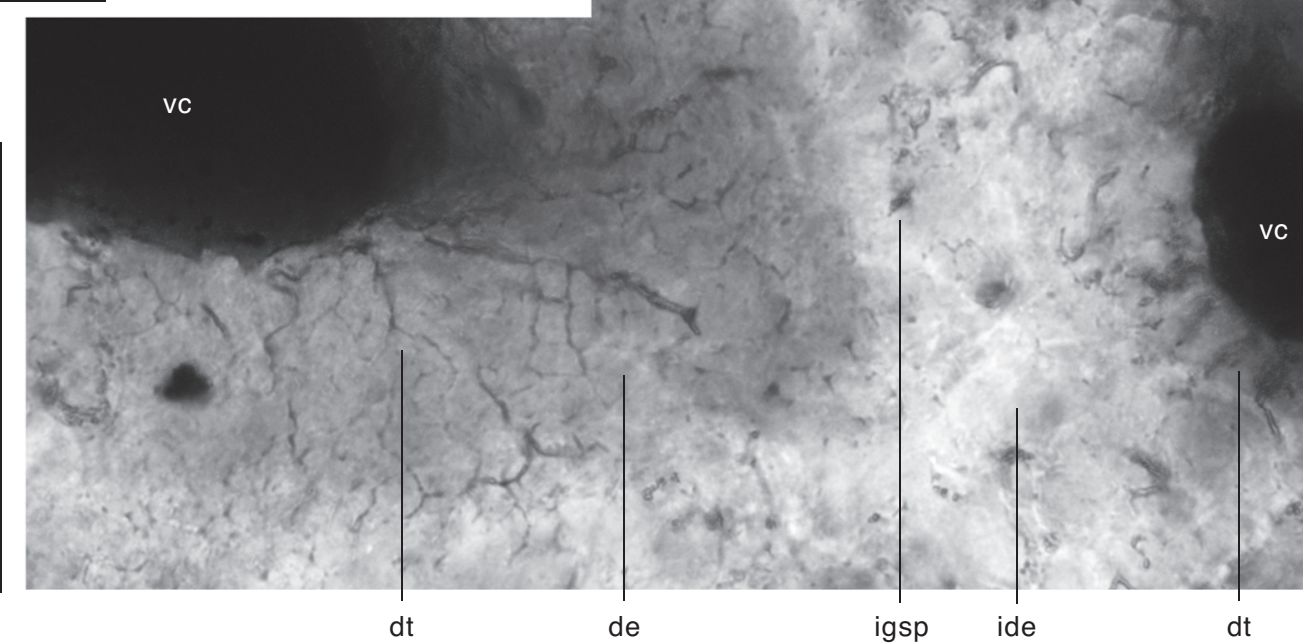

FIG. 7. - Machaeracanthus goujeti n. sp.; Lower Devonian, Iberian Chain. Transverse section of middle part of spine MPZ 2010/958, juvenile: A, general view of upper longitudinal ridge, wing and pulp cavity; B, C, details of the hard tissues in the wing close to the central axis, showing lamellar dentine with growth increment and trabecular dentine with denteons; $\mathbf{D}$, detail of centripetally growing trabecular dentine around the pulp cavity. Thin section observed in transmitted ordinary light. Abbreviations: see Material and methods Scale bars: A, $0.5 \mathrm{~mm}$; B, D, $0.1 \mathrm{~mm} ; \mathrm{C}, 50 \mu \mathrm{m}$. 

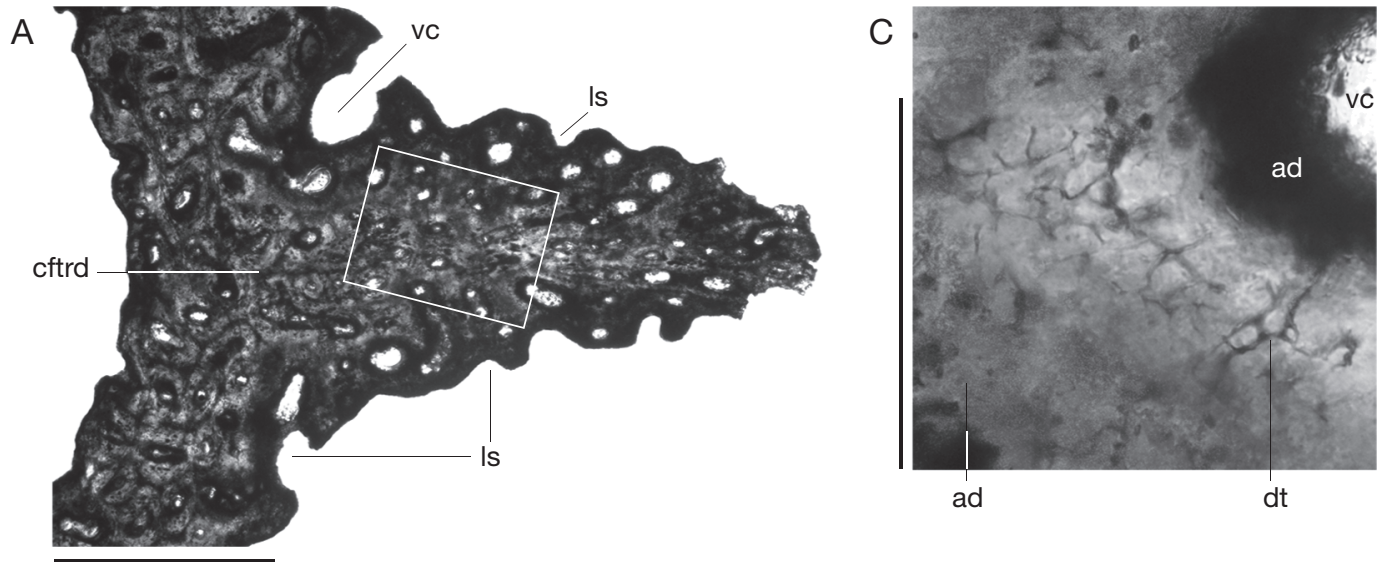

ad

$\mathrm{dt}$

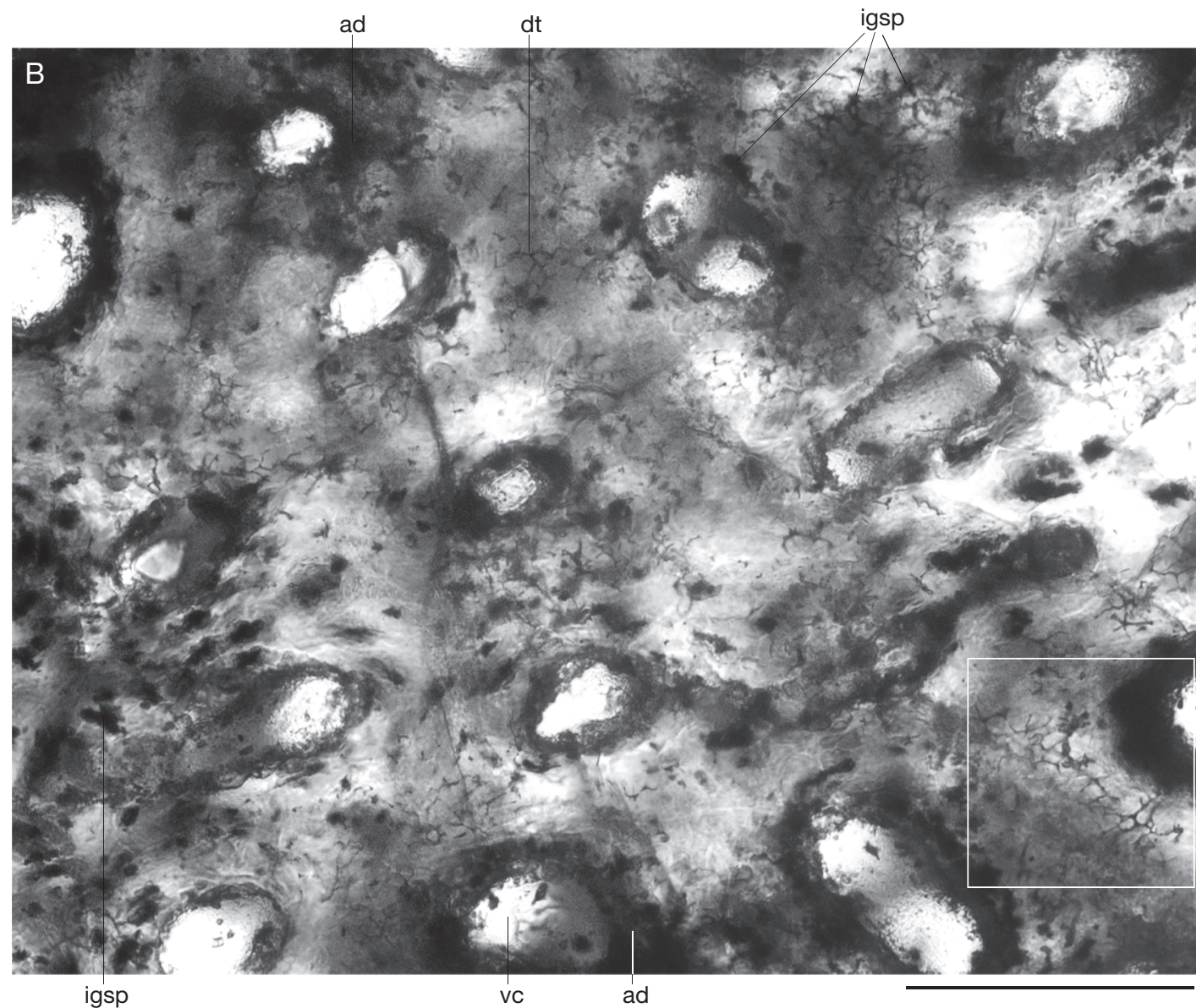

FIG. 8. - Machaeracanthus goujeti n. sp.; Lower Devonian, Iberian Chain. Transverse section proximal part of spine MPZ $2009 / 27$. A, general view of wing; B, detail of the wing (see framed area in A) showing trabecular dentine with taphonomic alteration; C, detail of $B$ exhibiting the dentinal tubules. Thin section observed in transmitted ordinary light. Abbreviations: see Material and methods. Scale bars: A, $0.5 \mathrm{~mm}$; B, $0.1 \mathrm{~mm}$; C, $50 \mu \mathrm{m}$. 
marked and do not follow the pattern of convergence to the center, but run subparallel along the crown (Fig. 9I). These forms are similar to some figured by Goujet (1976: pl. 61, figs 15-17). Others have an asymmetrical rounded crown (Fig. 9K), where the ridges are smooth and short and are arranged throughout the crown. These morphologies are not present in the material figured by Goujet (1976) and are very similar to the forms "verwachsene" and "schamale" figured by Wang (1993: pl. 15, figs 5, 6).

\section{Scale histology (Fig. 10)}

The crown is formed by apposed growth layers of mesodentine in the posterior part of the crown, and superposed growth layers in the anterior (Fig. 10A, $\mathrm{H})$. A dense network of dentine tubules and lacunae occupies the internal zones of growth layers, although in zones of the outermost part of every growth layer (especially in areas that correspond with ridges) the network of dentine tubules is less dense, with large sinuous branched tubules, and no lacunae, so that the tissue resembles orthodentine (Fig. 10G, H). No vascular canals can be identified either in the base or in the crown, although it may be due to fossilisation problems. The base shows numerous concentric growth lines consisting of successive alternating of dark and light layers (Fig. 10A, C, F). It is formed by cellular bone with some bone cell lacunae aligned with the different growth lines (Fig. 10F) and is pierced by numerous Sharpey's fibers, thick and arranged radially and obliquely (Fig. 10F). The apex of the base, immediately above the center of the crown, is often crystallized and occupied by calcite that hides the inner structure (Fig. 10C).

\section{Scapulocoracoid (Fig. 4L-O)}

Three right and two left perichondrally ossified scapulocoracoids of typical Machaeracanthus morphology (see Burrow et al. 2010b) occur associated with scales and spines of $M$. goujeti n. sp. All the scapulocoracoids found are of small size, the preserved height (dorso-ventrally) of the largest specimen MPZ 2010/952 (Fig. 4L-O) is $13 \mathrm{~mm}$ (estimated not more than $18 \mathrm{~mm}$ if it was complete). Unfortunately, none of the elements is entirely preserved, missing the dorsal end of the scapular shaft and, to a greater or lesser extent, the ventral areas of the scapulocoracoid blades. The preserved specimens show an elongate constricted scapular shaft, which is subcircular in cross section (about $0.25 \mathrm{~cm}$ in dimension anteroposterior), and a triangular scapulocoracoid portion (Fig. 4L, M). The transition between the scapular shaft and the triangular scapulocoracoidal areas is not abrupt but gradual, although the scapular shaft slightly narrows and bends anteriorly. The better preserved scapulocoracoid (MPZ 2010/952, Fig. 4L-O, broken during photography) shows a flat medial face on the blade while the preserved part of the lateral face slightly flares out in its most ventral part, consistent with the presence of a ventrolateral expansion of the scapulocoracoid.

\section{DISCUSSION}

\section{TAXONOMIC ASSESSMENT}

All the machaeracanthid elements found in Celtiberia (i.e. spines, scales and scapulocoracoids) appear repeatedly associated (but not articulated) in the same levels and all of them present a similar stratigraphic distribution (see Fig. 2), consequently we propose their inclusion in a single assemblage, all belonging to Machaeracanthus goujeti $\mathrm{n}$. sp. This association is congruent with previous Machaeracanthus assemblages from other localities (see Burrow et al. 2010b).

Mader (1986) and Wang (1993) figured and briefly described fragmentary spines from Lebanza Fm. (Palencia) and Nogueras Fm. (Celtiberia). The comparison with our material indicates that the specimen illustrated by Mader (1986: pl. 1, fig. 8) corresponds to the distal part (about $0.9 \mathrm{~cm}$ long, $4 \mathrm{~mm}$ maximum width) of a spine of morphotype 1 with the characteristic triangular upper longitudinal ridge.

The presence of spines of two different morphotypes within Celtiberian material is consistent with the presence of a pair of pectoral fin spines of different morphology on each side of the body as is known to occur in machaeracanthids (Burrow et al. 2010b).

Asymmetric spines of two different morphologies occur in the material from the Nogueras Fm. 


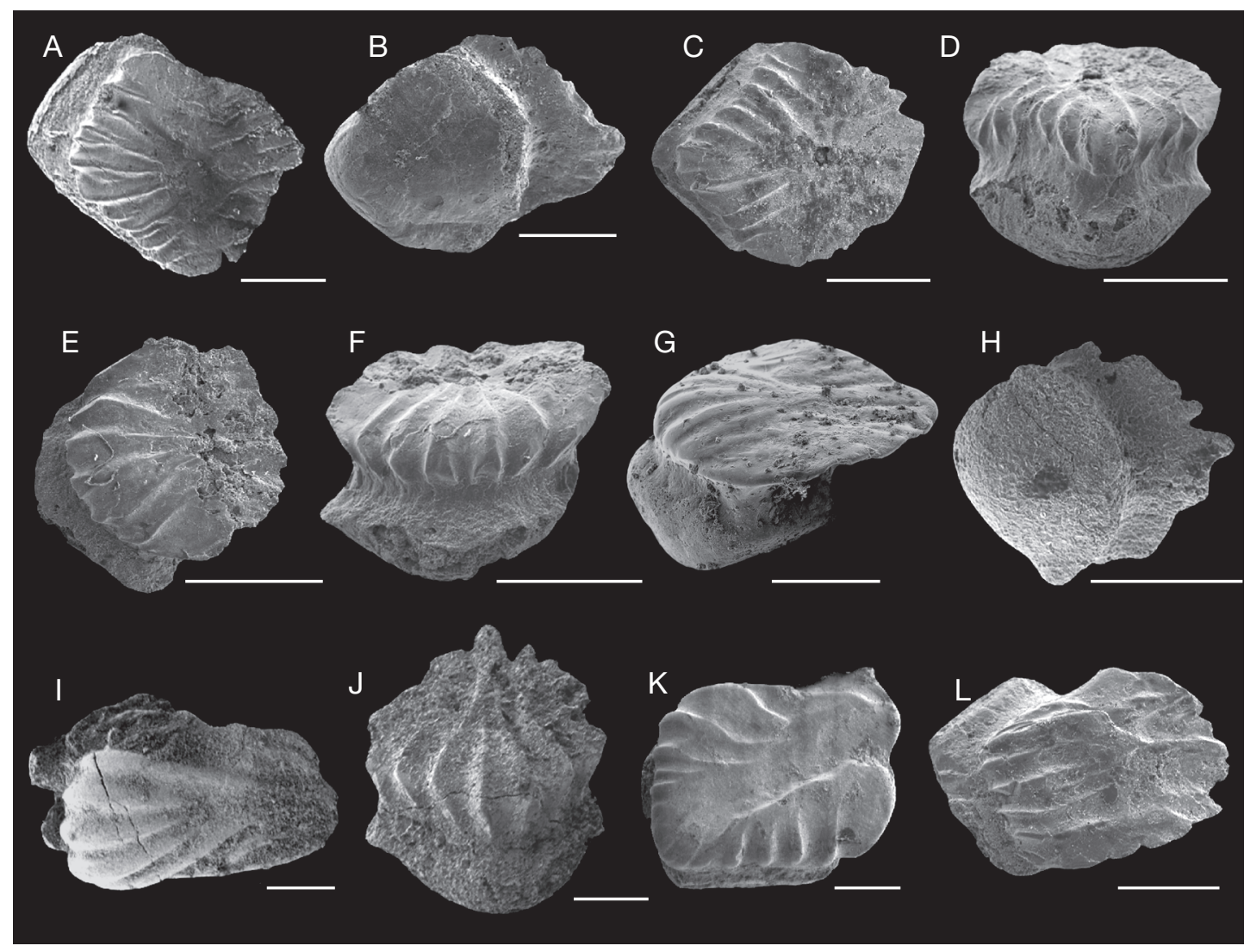

FIG. 9. - Scales of Machaeracanthus goujeti n. sp., Lower Devonian, Iberian Chain: A, B, element MGUV-15.075, Nogueras Fm, section Ni-2 (NI), in crown (A) and basal (B) views; C, D, element MGUV-15.077, Nogueras Fm., section Ni-2 (NI) in crown (C) and rostral (D) views; E, F, element MGUV-15.078, Nogueras Fm, section Ni-2 (NI), in crown (E) and rostral (F) views; G, element MPZ 2010/949, lateral view, Nogueras Fm., section Bco. Sur Sto. Domingo (ADRC); H, element MGUV-15.079, Nogueras Fm., section Bco. Sur Sto. Domingo (ADRC), basal view; I, element MGUV-15.080, Nogueras Fm., section Poyales-East (ADRC), crown view; J, element MGUV-15.082, Nogueras Fm., section Poyales-East (ADRC), crown view; K, element MGUV-15.081, Nogueras Fm., section Bco. Sur Sto. Domingo (ADRC), rostral view; L, element MGUV-15.076, Nogueras Fm, section Ni-2 (NI), anterior crown view. Scale bars: $\mathrm{A}-\mathrm{H}, \mathrm{L}, 500 \mu \mathrm{m} ; \mathrm{I}-\mathrm{K}, 250 \mu \mathrm{m}$.

studied here and both of them present machaeracanthid features (reviewed in Burrow et al. 2010b): saber shape, presence of two lateral expansions (an anterior keel and a posterior wing), that extend most of the length of the spine and absence of the " $U$ " shape transverse section characteristic of fin-spines of acanthodians and chondrichthyans.

The two morphotypes of $M$. goujeti n. sp. share small size, up to $c .10 \mathrm{~cm}$ maximum length as inferred from large fragments (Figs 4A-K; Fernández-Herrero et al. 2009: fig. 2B), maximum width to length ratio c. 1:7 (adult individuals), and in both, the keel and the wing are narrow and of approximately equal width; they differ in the cross sectional shape of the upper longitudinal ridge and in the degree of longitudinal striation. As we have still not found associated pairs of spines in a single slab in Celtiberia, we cannot rule out definitely the possibility that the two morphotypes belong to two different species. Nevertheless, the association of these two morphologies in a single species is in agreement with the model proposed by Südkamp \& Burrow 2007 (see also Burrow et al. 2010b), for Machaeracanthus with two unequal spines articulating on the 
shoulder girdle. The natural assemblage of pairs of spines, comprising a large one and small one, in the same slab has been documented in $M$. hunsrueckianum (Südkamp \& Burrow 2007) and M. longaevus (Burrow et al. 2010b). Additionally, Burrow et al. (2010b) proposed the association of two different spines morphotypes within $M$. sulcatus.

Machaeracanthus goujeti n. sp., shares with $M$. longaevus and $M$. sulcatus the presence of two spines with upper longitudinal ridge of different morphology in transverse section, one triangular and other square-shaped. However, spines of $M$. goujeti n. sp. have narrow lateral expansions of similar width in contrast to $M$. longaevus and $M$. sulcatus with keel wider than wing. In addition, the spines of $M$. longaevus and $M$. sulcatus are more slender than those from $M$. goujeti n. sp. On the other hand, cross sectional shapes of spines of $M$. major and $M$. bohemicus are similar to that of $M$. goujeti n. sp. morphotypes, but they can be distinguished from the new species by having wings wider than keels. Machaeracanthus peracutus shares with $M$. goujeti n. sp. the presence of lateral expansions of similar width; however, the spine of $M$. peracutus is more slender than those from the new species. Lastly, both $M$. goujeti n. sp. morphotypes differ clearly from $M$. peracutus, $M$. polonicus, $M$. kayseri or $M$. westfalicus in the cross sectional shape (compare Fig. 5 and Zidek 1981: fig. 2).

In addition to the scales from Celtiberia, we assign to M. goujeti n. sp. scales of Machaeracanthus sp. from Saint-Céneré Fm., northwest France (Goujet 1976), and scales of Machaeracanthus sp. A from Lebanza Fm. and La Vid Fm. in Northern Spain (Mader 1986).
Rouault (1858) erected two species, Machaerius archiaci and Machaerius larteti, for fragments of spines coming from the Mayenne department (Brittany, France), the same region of the scales studied by Goujet (1976). Unfortunately, the exact origin (locality and age) of the material was not indicated. These spines, not illustrated and poorly described, have been lost and the two species have been considered nomina vana (Zidek 1981).

Mader (1986) was the first author who pointed out the similarities between the Spanish and French material. Interestingly, Mader suggested that the complete assemblage could be a new species differing from $M$. bohemicus and $M$. stonehousensis, the latter being a species also identified in the Lower Devonian of Spain. Later, Wang (1993) distinguished between scales of Machaeracanthus sp. A (including the original material described by Mader and part of the material studied by Goujet) and Machaeracanthus sp. B (including here material from Celtiberia and one element of the French material); however, this variation probably corresponds to different topological scale types within a single taxon rather than a distinct species. It can also correspond to ontogenetic variation in the development of squamation; for example the small scales with a simple crown morphology (reduced number of ridges) figured by Goujet (1976: pl. 61, figs 7, 11) could belong to juvenile individuals.

As well as the distinctive arrangement of the growing dentine layers (see above), scales of $M$. goujet $i$ n. sp. also show the general morphology present in the scales of other Machaeracanthus species (i.e. M. bohemicus, M. pectinatus and M. stonehousensis): a crown ornamentation consisting of simple ridges

FIG. 10. - Machaeracanthus goujeti n. sp.; Lower Devonian, the lberian Chain. Ground thin sections of scales: A, B, MPZ 2010/960, Nogueras Fm., section Sur Barranco Santo Domingo (ADRC); A, general view of a vertical transverse section showing the coneshape base, and no wide vascular canals visible in the crown; $\mathbf{B}$, detail of the crown with growth lamellae, and mesodentine characterized by a network of lacunae and short tubules; C, vertical longitudinal section of scale MPZ 2010/961, Nogueras Fm., section Sur Barranco Santo Domingo (ADRC); the base is characterized by a cone shape with numerous concentric growth lines consisting of successive alternating of dark and light layers; D, F, vertical transverse section of scale MPZ 2010/962, Nogueras Fm., section Sur Barranco Santo Domingo (ADRC); D, detail of the crown showing the network of lacunae and short tubules characteristic of mesodentine; F, detail of the base with numerous concentric growth lines with some cell spaces "ostecyte cavities" aligned with them, besides numerous Sharpey's fibers arranged radially and obliquely are visible; E, G, horizontal section crown of scale MPZ 2010/963, Nogueras Fm., section Sur Barranco Santo Domingo (ADRC); E, the mesodentine is characterized by a network of lacunae and short tubules that are developed mainly in the front of the crown $\mathbf{G}$, detail of the previous picture; $\mathbf{H}$, vertical longitudinal section of scale MPZ 2010/964, Nogueras Fm., section Sur Barranco Santo Domingo (ADRC); detail of the anterior region of the crown showing the growth lamella and the network of lacunae and short tubules characteristics of the mesodentine. Abbreviations: see Material and methods. Scale bars: $100 \mu \mathrm{m}$. 

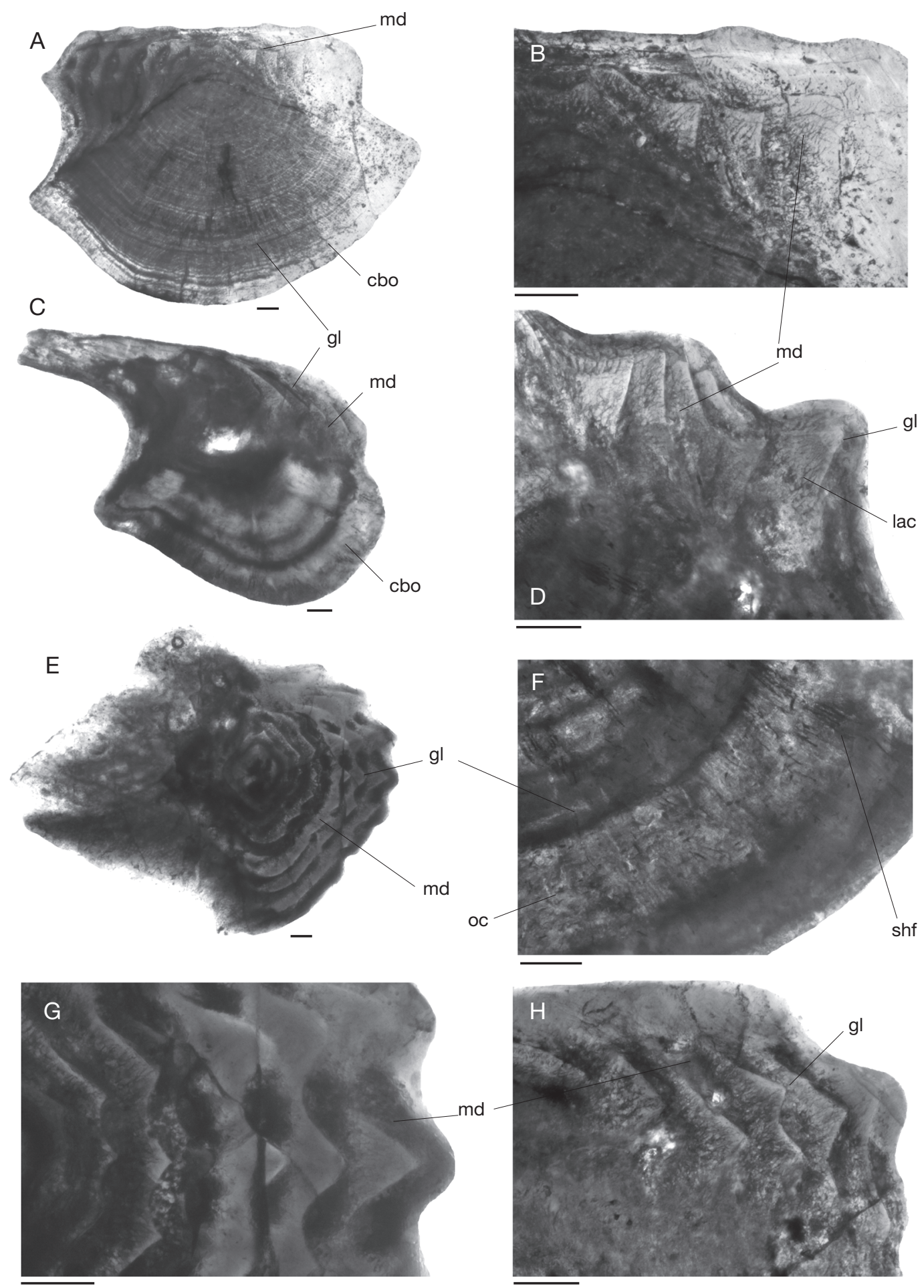
which tend to converge toward the centre of the scale and posteriorly diverge and the denticulation at the caudal margin of the crown (see Figure 9). Scales of $M$. goujeti n. sp. resemble those of $M$. bohemicus, but as Goujet (1976) pointed out, they can be clearly distinguished by the lower protrusion of the base present in the latter species (see Gross 1973: pl 28, figs 21c, 22b; pl. 29, figs 6-8) and from the lateral aspect of the crown ribs (see Mader 1986: 30). Additionally, the posterior crown margin is markedly pointed in M. bohemicus (Gross 1973: pl. 29, figs 1-5) but not in the new species.

The base of $M$. goujeti n. sp. scales is of cellular bone and mesodentine forms most of the crown. This histological structure differs from $M$. bohemicus and $M$. pectinatus, where orthodentine forms most of the crown and no cell lacunae are present in the base (Burrow \& Young 2005). Otherwise, M. stonehousensis presents "stranggewebe"-like tissue (Mader 1986; Vergossen 1995, 2000) and radial rows of crown pores (Vergoossen 1995; 2000), features absent in other described Machaeracanthus scales. Because of these pore rows, Vergoossen (1995, 2000) did not include M. stonehousensis within the genus and considered this species to be a poracanthodid ischnacanthiform. Nevertheless, Burrow et al. (2010b) based on an unpublished manuscript by Denison supported its assignment to Machaeracanthus.

Scapulocoracoids themselves are probably the least diagnostic machaeracanthid elements, showing a morphology similar to those of ischnacanthiforms but with an extra ventrolateral expansion (Burrow et al. 2010b). Scapulocoracoids from Celtiberia present a slender scapular shaft which broadens out to a triangular blade, similar to those of other Machaeracanthus species (compare with Burrow et al. 2010b: fig. 5). Unfortunately, all specimens from Celtiberia are incomplete, lacking the ventral areas of the scapulocoracoid blades, so that we cannot definitively assert the presence of a ventrolateral expansion, although the most complete specimen suggests it (see above).

\section{SIZE AND ONTOGENY}

Fritsch (1893) and Gross (1965) speculated about the absolute size of individuals of Machaeracanthus species and estimated a total length of about $200 \mathrm{~cm}$ for Machaeracanthus bohemicus and 140-170 cm for Machaeracanthus sp. (originally identified as Gemuendolepis muelleri Gross, 1973) from the Hunsrück Slate. Still the fossil record of Machaeracanthus is composed of isolated elements, mainly spines and scales (see Introduction), so that the allometric relationship between the skeletal elements and the body of the fish is unknown, hampering estimation of the length of the individuals belonging to different species. However, we can compare the dimensions of the dermal spines of the recorded species and assume that the size of the Machaeracanthus spines is an appropriate indicator of the complete size of the individual, in similar fashion to most acanthodians known from a more complete fossil record (e.g. Upeniece 1996; Zajíc 1998, 2005). In this respect, $M$. goujeti $\mathrm{n}$. sp. appears to be a small species, similar in size to $M$. peracutus and $M$. sulcatus. Large spines of $M$. goujeti n. sp. c. $1.5 \mathrm{~cm}$ wide and $c .10 \mathrm{~cm}$ long (inferred length) are comparable in size to those of $M$. peracutus and $M$. sulcatus which are $c .1 \mathrm{~cm}$ in width and $10-15 \mathrm{~cm}$ in length (Burrow et al. 2010b). In contrast, $M$. goujeti n. sp. differs from $M$. bohemicus, $M$. longaevus and $M$. major, which present large spines more than $20 \mathrm{~cm}$ in length and can reach 20-35 $\mathrm{mm}$ in maximum width (Burrow et al. 2010b).

Several very small spines of $M$. goujeti $n$. sp., less than $0.5 \mathrm{~cm}$ in width, probably belong to juvenile individuals. Specimen MPZ 2010/950 (Fig. 3), the smallest nearly complete spine of $M$. goujeti n. sp. is the best example, found by acid preparation of the fossiliferous limestones. In addition to the extremely small size, the specimen differs in several morphological features from the other, larger spines form the new species and the other Machaeracanthus spines described until now (see review in Burrow et al. 2010b). The spine in its distal part (about one fourth of the total length) lacks lateral expansions and presents a diamond-shaped transverse section. Although the actual spine is relatively robust with a ratio of maximum width to length of $1: 4$, it could originally be slender with a longer region lacking lateral expansions as suggested by the distal worn surface. Interestingly, an unpublished small specimen MB f. 14194 (Machaeracanthus sp.) (27 mm 
long, lacking the proximal end) from the Eifelian (?) of Müllerberg near Nettersheim (Germany) exhibits a distal half without lateral expansions ranging $0.5-1 \mathrm{~mm}$ in width; the proximal half of the specimen, $4 \mathrm{~mm}$ in maximum width, presents the usual Machaeracanthus morphology with well developed keel and wing, lateral to the central axis. The distal part of the juvenile spine lacking lateral expansions, document the first stage in the development of the spine.

The presence of juveniles of $M$. goujeti n. sp. in the Spanish localities is also suggested by the size of the scapulocoracoids associated to the spines. The elements from Celtiberia are significantly smaller than that from $M$. sulcatus. The scapulocoracoids of $M$. goujeti n. sp. are not more than $18 \mathrm{~mm}$ in height (inferred height) whereas those from $M$. sulcatus reach $43 \mathrm{~mm}$. The scapulocoracoids of $M$. major and $M$. bohemicus are even larger than those from $M$. sulcatus, in agreement with their enormous spines. As a good example a very large complete scapulocoracoid of M. major is $300 \mathrm{~mm}$ high (Burrow et al. 2010b).

\section{SPINE HISTOLOGY}

Several authors have studied the microstructure and histology of the spines of Machaeracanthus: Barrande (1872); Gross (1933); Wells (1944); Ørvig (1951); Denison (1979); Zidek (1975, 1981); Young (1986); Webers et al. (1992); Anderson et al. (1999); Burrow \& Young (2005); Südkamp \& Burrow (2007), Fernández-Herrero et al. (2009) and Burrow et al. (2010b).

In a preliminary note, Fernández-Herrero et al. (2009) gave the first description of the histology of the spines from Celtiberia. The authors described the wall of the spine as consisting mainly of "compact cellular bone highly vascularized" with the development of osteons and osteocytes. Fernández-Herrero et al. (2009: fig. 3C, D) also distinguished in some sections the presence of an "internal layer, in contact with the central cavity [pulp cavity] of a darker colour and with numerous cellular (?) rounded spaces". Our re-study of the original material indicates that the so-called bone and osteocytes correspond to altered interglobular dentine with interglobular spaces infilled by authigenic minerals resembling bone-cell lacunae (Soler-Gijón 1999: figs 11B; 16B, C; Sansom et al. 2005: 380, fig. 2B, D). Dentine tubules, which were not recognized by FernándezHerrero et al. (2009), still remain in a few areas of the sections despite harsh diagenetic alteration (see Fig. 8). Interglobular dentine, representing areas with weak mineralization during dentinogenesis, has been described in dermal spines and teeth from Palaeozoic to Recent, and from chondrichthyans to mammals (see Soler-Gijón 1999 and references therein). On the other hand, the darker internal layer of the spine wall surrounding the pulp cavity described by Fernandez-Herrero et al. (2009) corresponds to an authigenic cement (ferruginous or phosphatic) covering the trabecular dentine and infilling the vascular canals connected with the pulp cavity. Pulp cavity, vascular canals and interglobular spaces are optimal microenvironments for taphonomic alteration mediated by microorganisms (Kierdorf et al. 2009 and references therein) and for precipitation of authigenic minerals (pyrite, apatite, hematite: Wings 2004; Rogoz et al. 2009).

The general microstructure and vascular pattern of the distal/middle parts of the spine of $M$. goujet $i$ n. sp. (i.e. inner, centripetally growing trabecular tissue with wide intertrabecular spaces, surrounding the pulp [central] cavity and outer, more compact, centrifugally growing tissue; see Fig. 5A, B, D) is also illustrated and/or briefly described in $M$. bohemicus (Barrande 1872: pl. 28, figs 7, 25, 26; pl. 34, fig. 32), M. kayseri (Gross 1933: fig. 12B), M. cf. kayseri (Early Devonian, Antarctica; Webers et al. 1992: 274-275), M. hunsrueckianum (Südkamp \& Burrow 2007: fig. 2B, C) and Machaeracanthus sp. (Emsian, Antarctica; Young 1986: fig. 2B). In addition, the morphology of the proximal part of the spine of Machaeracanthus as described in M. goujeti n. sp. (i.e., compact trabecular tissue bounding a wide pulp cavity; see Fig. 5C) is also figured for $M$. bohemicus (Barrande 1872: pl. 28, figs 5, 9; pl. 30, fig. 8) and M. cf. kayseri (Webers et al. 1992: fig. 3A). These comparative results suggest that the microstructure of $M$. goujeti $\mathrm{n}$. sp. described here for distal, middle and proximal parts are representative of the general structure in the Machaeracanthus spine.

The spines of $M$. goujeti n. sp. consist of dentine only, and this was probably the case for the majority 
or even all of the species of the genus. Recently, Burrow et al. (2010b: fig. 3G), figured and described denteons, dentine tubules and interdenteonal areas lacking cell lacunae in osteodentine (called trabecular dentine in this paper) surrounding the pulp (central) cavity of the spine of $M$. peracutus. Machaeracanthus goujeti n. sp. and $M$. peracutus also share the absence of outer ortho- or mesodentine layers, a condition which clearly distinguishes Machaeracanthus from the other acanthodians (Burrow et al. 2010b: 65). In this respect, we have to note here that the smooth longitudinal carination ornamenting the Machaeracanthus spines develop by the regular deposition of centrifugal dentine in constrast to the longitudinal ridges of other acanthodians (e.g., climatiforms, acanthodiforms) which develop by centripetal deposition of orthoor mesodentine (Denison 1979; Beznosov 2009). Interestingly, longitudinal striation with centrifugal dentine appears in dorsal spines of xenacanth sharks (cf. Soler-Gijón 1999) which suggests developmental similarities between Machaeracanthus and some primitive chondrichthyans.

Machaeracanthus bohemicus also shares with $M$. goujeti n. sp. the presence of osteodentine lacking cell lacunae (cf. Burrow et al. 2010b: 76). The presence of interdenteonal cell lacunae in $M$. major (Wells 1944; Ørvig 1951) was not confirmed by Burrow et al. (2010b: 69).

True cellular bone is described and figured by Burrow \& Young (2005: fig. 8) in isolated small dermal elements tentatively identified as "Fin ray or spine elements" possibly from $M$. pectinatus (? late Emsian/early Eifelian of the Craven Peaks Beds, Georgina Basin, western Queensland, Australia). Although these dermal elements are associated with Machaeracanthus scales (see Burrow \& Young 2005, fig. 7), they are deeply different from the spines of $M$. goujeti $n$. sp. and other species of the genus discussed above. The dermal elements of Craven Peaks Beds superficially resemble Machacaeracathus spines in transverse sectional shape. However they lack the central pulp cavity and the extremely regular vascular pattern, with denteons shown by the Machaeracanthus spines (see above). The general morphology (partially bifurcated) and histology (cellular bone and possibly Williamson's canals) of these elements correspond to fin rays of actinopterygians (e.g., Arratia 2008), but no other possible actinopterygian skeletal elements are found in the Cravens Peak Beds

Our results from $M$. goujeti n. sp. are relevant to continue the discussion by Burrow \& Young (2005) who tried to explain the possible origin of the particular morphology of Machaeracanthus spines, so different to the rest of the acanthodians (see Janvier 1996). Based on the morphology of the possible "fin spines/rays" of $M$. pectinatus, Burrow \& Young (2005: 20-21) indicated that "If machaeracanthids derived from an ischnacanthiform ancestor, perhaps Machaeracanthus spines developed by enlargement of the fin basals after loss of the pectoral fin spines". Spines of $M$. goujeti n. sp. are different in morphology and histology from fin spines, fin rays and radials of teleostomes. In contrast, Machaeracanthus presents some features found in dentine spines of some chondrichthyans (e.g., xenacanths). A detailed study of the histology of the spines of Machaeracanthus, including serial cross sections, (in progress) will give information about their growth and development and could provide new information on the affinities of the genus.

\section{Biostratigraphy and Palaeobiogeography} The stratigraphic distribution of $M$. goujeti $\mathrm{n}$. sp. in Celtiberia, shown in Figure 2, ranges from unit $\mathrm{d} 2 \mathrm{a} \alpha$ (middle-late Lochkovian) to unit $\mathrm{d} 2 \mathrm{c} \beta$ (early Pragian) being relatively continuous during the entire interval. Thus, the only coeval species of $M$. goujeti n. sp. is $M$. bohemicus from the Lochkovian of the Czech Republic, with other Machaeracanthus species known from younger strata (middle Pragian to Eifelian) with the exception of the Late Silurian species $M$. stonehousensis of eastern Canada, which is known only from scales. Remarkably, both species, $M$. goujeti n. sp. and M. bohemicus, are so far the only Machaeracanthus species known from associated spines, scales and scapulocoracoids.

The stratigraphical and palaeogeographical distribution of the oldest machaeracanthids (i.e. $M$. stonehousensis, $M$. bohemicus and $M$. goujeti n. sp.) suggest an origin for the genus in seas surrounding Gondwana-derived terranes (including Ibero-Armorican and Bohemian massif) during 
the Late Silurian and then distributed worldwide (North America, Africa, Australia and Antarctica) during Pragian-Emsian times. The dispersion of Machaeracanthus and other organisms could be favoured by the development of large marginal marine areas. As commented above, the Nogueras Fm. consist of neritic sediments, with some episodes of high shallowing during the Late Lochkovian (unit d2aß5) (see Carls 1999; Dojen 2005). These shallow near-coastal marine environments offer a number of restricted and protected areas from open seas which could have been a perfect place for development and growth of juvenile and adult Machaeracanthus, although the adult forms probably also inhabited deeper water environments, as usually occurs in recent fishes. The frequent changes in the subsidence of the Celtiberian Basin during Lochkovian and Pragian times, often associated with high shallowing events (Carls 1999), facilitated the dispersion (and interchange) of shallow-water faunas of Celtiberia, as has been recently documented for ostracods (Dojen 2005), primitive chondrichthyans (Martínez-Pérez et al. 2010), and placoderms (Dupret et al. 2011).

\section{CONCLUSIONS}

The study of numerous spines from the Lower Devonian of Celtiberia has confirmed the presence of a new species, $M$. goujeti n. sp., very different in morphology and size to the coeval species M. bohemicus. Machaeracanthus goujeti n. sp. comprises two morphotype spines in similar fashion to $M$. hunsrueckianum, $M$. longaevus and $M$. sulcatus. In this respect, the new material from Celtiberia supports the morphofunctional model for pectoral girdle-spines of Machaeracanthus proposed by Südkamp \& Burrow (2007). The model, based on partial articulated/associated material indicates that a pair of spines articulated with the pectoral girdle (see Burrow et al. 2010b: fig. 5 I).

Juvenile spines and scapulocoracoids of $M$. goujeti n. sp. are the first record of juvenile individual of Machaeracanthus. The distal part of the juvenile spine lacks lateral expansions (keel and wing, typical in the "adult" Machaeracanthus morphology) documenting the first stage in the development of the spine.

The spine of $M$. goujeti $n$. sp. (morphotypes 1 and 2) exhibits an elongated pulp cavity which opens proximally. The wall of the central axis of the spine surrounding the pulp cavity, and the lateral expansions, consist of dentine. Centripetally growing trabecular dentine obliterates the pulp cavity in the distal and middle parts of the spine. Centrifugally growing dentine (trabecular and lamellar) forms the rest of the spine without development of an ornament with longitudinal ribs of ortho- or mesodentine on the exserted part.

The morphology and histology of Machaeracanthus, as seen in M. goujeti n. sp., differ from those of fin rays and radials of acanthodians and osteichthyans. The results presented here are in disagreement with Burrow \& Young (2005) who proposed that the Machaeracanthus spine developed by enlargement of the fin rays or radials of some ischnacanthiform acanthodian.

\section{Acknowledgements}

We thank Dr Peter Carls (Technical University of Braunschweig) who loaned part of the studied material. We would like to thank the referees, Carole Burrow (University of Queensland) and Daniel Goujet (Muséum national d'Histoire naturelle), for all the suggestions which improved the quality of our work. We are greatly indebted to E. Siebert (Museum für Naturkunde, Berlin) for preparing the final version of the figures 3, 5-8 and Dr Vincent Dupret (Uppsala University) for his help with the French translation. This work has been partially supported by project BFU2008-00643/BFI of the Ministerio de Ciencia e Innovación, and is a contribution to the IGCP 596-IUGS.

\section{REFERENCES}

Anderson M. E., Almond J. E., Evans, F. J. \& Long J. 1999. - Devonian (Emsian-Eifelian) fish from the Lower Bokkeveld Group (Ceres Subgroup), South Afric. Journal of African Earth Sciences 29: 179-194.

ARRATIA G. 2008. - Actinopterygian postcranial skeleton with special reference to the diversity of fin ray 
elements, and the problem of identifying homologies, in Arratia G., Schultze H.-P. \& Wilson M. V. H. (eds), Mesozoic Fishes 4-Homology and Phylogeny. Verlag Dr. F. Pfeil, München: 49-101.

BARRANDE J. 1872. - Système silurien du centre de la Bohème. Ière Partie: Recherches paléontologiques. Supplement au Vol. I. Trilobites, crustacés divers et poissons. C. Bellman, Prague/Paris: 647 p.

BeZnosov P. 2009. - A redescription of the Early Carboniferous acanthodian Acanthodes lopatini Rohon, 1889. Acta Zoologica 90 (suppl. 1): 183-193.

Botella H. \& ValenZuela-Ríos J. I. 2005. — Análisis comparativo de microvertebrados fósiles del límite Lochkoviense/Praguiense (Devónico Inferior) en la Depresión Axial del río Cámaras. Teruel 88: 45-68.

BRAZEAU M. D. 2009. - The braincase and jaws of a Devonian "acanthodian" and modern gnathostome origins. Nature 457: 305-308.

Burrow C. J. \& Young G. C. 2005. - The acanthodian fauna of the Craven Peaks Beds (Early to Middle Devonian), Western Queensland. Memoirs of the Queensland Museum 51: 3-25.

Burrow C. J., Turner S. \& Young G. C. 2010a. Middle Palaeozoic microvertebrate assemblages and biogeography of East Gondwana (Australasia, Antarctica). Palaeoworld 19: 37-54.

Burrow C. J., Desbiens S., EkrT B. \& SÜdKAmp,W. H. 2010b. - A new look at Machaeracanthus, in ELLiotT D. K., Maisey J. G., Yu X. \& MiaO D. (eds), Morphology, Phylogeny and Paleobiogeography of Fossil Fishes. Verlag Dr. F. Pfeil, München: 59-84.

CARLS P. 1988. - The Devonian of Celtiberia (Spain) and Devonian paleogeography of SW Europe, in McMillan N. J., Embry A. F. \& Glass D. J. (eds), Devonian of the World. Memoir of the Canadian Society of Petroleum Geologist, Calgary: 421-266.

CARLS P. 1999. — El Devónico de Celtiberia y sus fósiles, in Gámez Vintaned J. A. \& Liñan E. (eds), Memorias de las VI Jornadas Aragonesas de Paleontología. "25 Años de Paleontología Aragonesa" Homenaje al Prof. Leandro Sequeiros. Institución Fernando el Católico: 101-164.

Carls P. \& Valenzuela Ríos J. I. 2002. - DevonianCarboniferous rocks from the Iberian Cordiellera, in García-López S. \& Bastida F. (eds), Palaeozoic conodonts from Northern Spain. Instituto Geológico y Minero de España, Serie Cuadernos del Museo Geominero, Madrid: 299-314.

Denison R. H. 1979. - Acanthodii, in Schultze H.P. (ed.), Handbook of Paleoichthyology, Vol. 5. Gustav Fischer Verlag, Stuttgart, New York: 62 p.

Dojen C. 2005. - Early Devonian ostracods of Celtiberia (NE Spain) - Taxonomy, palaeoecology, biostratigraphy and biogeography. Technische Universität, Braunschweig: $256 \mathrm{p}$.

Dupret V., Carls P., Martinez-Perez C. \& Botella H. 2011. - First perigondwana record of actinolepids
(Vertebrata: Placodermi: Arthrodira) from the Lochkovian (Early Devonian) of Spain and its palaeobiogeographic significance. Palaeogeography, Palaeoclimatology, Palaeoecology 310: 273-282.

Fernández-Herrero S., Gil-Sifre U., MarTínez-PéreZ C. \& Botella H. 2009. - Morfología e histología de espinas de Machaeracanthus (Acanthodii) del Devónico Inferior de la Cordillera Ibéric. Paleolusitana 1: 177-182.

FriTSCH A. 1893. - Fauna der Gaskohle und der Kalksteine der Permformation Böhmens. Selachii (Traquairia, Protacanthus, Acanthodes). Actinopterygii (Megalichthys, Trissolepis) 3 (2): 49-80. Prague.

GoujeT D. 1976. - Les Poissons, in Lardeux H. (ed.), Les Schistes et Calcaires Éodévoniens de Saint-Céneré (Massif Armoricain, France), sédimentologie, paléontologie, stratigraphie. Mémoirs de la Societé Géologique et Minéralogique de Bretagne 19: 313-323.

Gross W. 1933. - Die unterdevonischen Fische und Gigantostraken von Overath. Abhandlungen der Preußischen Geologischen Landesanstalt, Neue Folge 145: 41-77.

GROSS W. 1965. - Über einen neuen Schädelrest von Stensiöella heintzi und Schuppen von Machaeracanthus sp. indet. aus dem Hunsrückschiefer. Notizblatt des Hessischen Landesamtes für Bodenforschung 93: 7-18.

Gross W. 1973. - Kleinschuppen, Flossenstacheln und Zähne von Fischen aus europäischen und nordamerikanischen Bonebeds des Devons. Palaeontographica (A) 142: 51-155.

Hanke G. F. \& Wilson M. V. H. 2010. — The putative stem-group chondrichthyans Kathemacanthus and Seretolepis from the Lower Devonian MOTH locality, Mackenzie Mountains, Canada, in ElliotT D. K., Maisey J. G., Yu X. \& MiaO D. (eds), Morphology, Phylogeny and Paleobiogeography of Fossil Fishes. Verlag Dr. F. Pfeil, München: 159-182.

JanVier P. 1996. — Early Vertebrates. Oxford University Press, $393 \mathrm{p}$.

KegeL W. 1913. - Der Taunusquarzit von Katzenelnbogen. Jahrbuch der Preussischen Geologischen Landesanstalt N.F. 76: 1-163.

Kierdorf H., Kierdorf U., Witzel C., Intoh M. \& Dobney K. 2009. - Developmental defects and postmortem changes in archaeological pig teeth from Fais Island, Micronesia. Journal of Archaeological Science 36: 1637-1646.

LEGAULT J. A. 1968. - Conodont and fish remains from the Stonehouse Formation, Arisaig, Nova Scotia. Canada Geological Survey Bulletin 165: 3-48.

MADER H. 1986. - Schuppen und Zähne von Acanthodiern und Elasmobranchiern aus dem Unter-Devon Spaniens (Pisces). Göttinger Arbeiten zur Geologie und Paläontologie 28: 1-59.

Maisey J. G. \& Melo J. H. G. 2005. — Some Middle Devonian (Eifelian-Givetian) fossil fish remains from the Pimenteira Formation of the Parnaíba Basin, 
Northeast Brazil. Arquivos do Museu Nacional Rio de Janeiro 63 (3): 495-505.

Maisey J. G., Borghi L. \& De Carvalho M. G. P. 2002. - Lower Devonian fish remains from the Falkland Islands. Journal of Vertebrate Paleontology 22: 708-711.

Martínez-Pérez C., Dupret V., Manzanares E. \& Botella H. 2010. - New data on the Lower Devonian chondrichthyan fauna from Celtiberia. Journal of Vertebrate Paleontology 30: 1622-1627.

Morzadec P., Paris F., Plusquellec Y., Racheboeuf P.-R. \& WEYANT M. 1991. — La limite LochkovienPraguien (Dévonien inférieur) dans le Massif armoricain: espèces index et corrélations. Comptes Rendu de l'Academie des Sciences de Paris 313 (II): 901-908

NewberRY J. S. 1857. - Fossil fishes from the Devonian rocks of Ohio. Proceedings of the National Institute for the Promotion of Science 1 (n.s.): 119-126.

ØRVIG T. 1951. - Histologic studies of placoderms and fossil elasmobranches. 1: The endoskeleton, with remarks on the hard tissues of lower vertebrates in general. Arkiv För Zoologi 2: 321-454.

Rogoz A., Sawlowicz Z., Socha P. \& Stefaniak K. 2009. - Mineralization of teeth and bones of the cave bear (Ursus spelaeus) from the Bisnik Cave, Southern Poland. Mineralogia 40: 65-84.

Rouault M. 1858. — Note sur les Vertébrés fossils des terrains sédimentaires de l'Ouest de la France. Comptes Rendu de l'Academie des Sciences de Paris 47: 99-103.

Sansom I. J., Wang N.-Z. \& Smith M. 2005. - The histology and affinities of sinacanthid fishes: primitive gnathostomes from the Silurian of China. Zoological Journal of the Linnean Society 144: 379-386.

SOLER-GIJON R. 1999. - Occipital spine of Orthacanthus (Xenacanthidae, Elasmobranchii): structure and growth. Journal of Morphology 242: 1-45.

SÜDKAMP W. H. \& BURROW C. J. 2007. - The acanthodian Machaeracanthus from the Lower Devonian Hunsrück Slate of the Hunsrück region (Germany).Paläontologische Zeitschrift 81 (1): 97-104.

UPENIECE I. 1996. - Lodeacanthus ganjicus n. g. et sp. (Acanthodii: Mesacanthidae) from the Late Devonian of Latvia. Modern Geology 20: 383-398.

VAlenZuELA-Ríos J. I. 1989. — El Paleozoico de Nigüella (nota preliminar). Azuara 1: 35-43.
ValenZuela-Ríos J. I. \& Botella. H. 2000. — Datos preliminares sobre la fauna de vertebrados (Pisces) del Devónico Inferior de Nigüella (Cadenas Ibéricas). Geogaceta 28: 153-156.

VERGOOSEN J. M. J. 1995. - Remarks on microremains of Acanthodians (Gnathostomata) from the Late Pridoli of Manbrook (Upper Silurian, Great Britain). Geobios Special Memoir 19: 399-401.

Vergoosen J. M. J. 2000. - Acanthodian and chondrichthyan microremains in the Siluro-Devonian of the Welsh Borderland, Great Britain, and their biostratigraphical potential. Courier Forschungsinstitut Senckenberg 223: 175-199.

WANG R.-H. 1993. - Taxonomie, Palökologie und Biostratigraphie der Mikroichthyolithen aus dem Unterdevon Keltiberiens, Spanien. Courier Forschungsinstitut Senckenberg 161: 1-205.

Webers G. F., Glenister B., Pojeta J. Jr. \& Young G. 1992. - Devonian fossils from the Ellsworth Mountains, West Antarctica, in Webers G. F., CrADDOCK C. \& Splettstoesser J. F. (eds), Geology and Paleontology of the Ellsworth Mountains, West Antarctic. Geological Society of America Memoir 170: 269-278.

WeLlS J. W. 1944. — Fish remains from the Middle Devonian Bone Beds of the Cincinnati Arch region. Palaeontographica Americana 3: 99-160.

Wings O. 2004. - Authigenic minerals in fossil bones from the Mesozoic of England: poor correlation with depositional environments. Palaeogeography, Palaeoclimatology, Palaeoecology 204: 15-32.

Young V. T. 1986. - Early Devonian fish material from the Horlick Formation, Ohio Range, Antarctic. Alcheringa 10: 35-44.

Zajíc J. 1998. - Acanthodians of the Bohemian limnic Stephanian. Czech geological Survey Special Papers 10: $1-44$

ZAjíc J. 2005. - Permian acanthodians of the Czech Republic. Czech geological Survey Special Papers 18: 1-42.

ZIDEK J. 1975. - Oklahoma paleoichthyology, pt. 4, Acanthodii. Oklahoma Geology Notes 35: 135-146.

ZIDEK J. 1981. - Machaeracanthus Newberry (Acanthodii: Ischnacanthiformes) - morphology and systematic position. Neues Jahrbuch für Geologie und Paläontologie, Monatshefte 12: 742-748.

Submitted on 10 April 2011; accepted on 27 September 2011. 